\title{
A global simulation of brown carbon: implications for photochemistry and direct radiative effect
}

\author{
Duseong S. Jo ${ }^{1}$, Rokjin J. Park ${ }^{1}$, Seungun Lee ${ }^{1}$, Sang-Woo Kim ${ }^{1}$, and Xiaolu Zhang ${ }^{2}$ \\ ${ }^{1}$ School of Earth and Environmental Science, Seoul National University, Seoul, 151-747, Republic of Korea \\ ${ }^{2}$ Department of Civil and Environmental Engineering, University of California, Davis, CA, USA
}

Correspondence to: Rokjin J. Park (rjpark@snu.ac.kr)

Received: 20 July 2015 - Published in Atmos. Chem. Phys. Discuss.: 15 October 2015

Revised: 3 March 2016 - Accepted: 3 March 2016 - Published: 16 March 2016

\begin{abstract}
Recent observations suggest that a certain fraction of organic carbon (OC) aerosol effectively absorbs solar radiation, which is also known as brown carbon $(\mathrm{BrC})$ aerosol. Despite much observational evidence of its presence, very few global modelling studies have been conducted because of poor understanding of global $\mathrm{BrC}$ emissions. Here we present an explicit global simulation of $\mathrm{BrC}$ in a global 3-D chemical transport model (GEOS-Chem), including global $\mathrm{BrC}$ emission estimates from primary $(3.9 \pm 1.7$ and $3.0 \pm 1.3 \mathrm{TgC} \mathrm{yr}^{-1}$ from biomass burning and biofuel) and secondary (5.7 $\mathrm{TgC} \mathrm{yr}^{-1}$ from aromatic oxidation) sources. We evaluate the model by comparing the results with observed absorption by water-soluble OC in surface air in the United States, and with single scattering albedo observations at Aerosol Robotic Network (AERONET) sites all over the globe. The model successfully reproduces the seasonal variations of observed light absorption by water-soluble OC, but underestimates the magnitudes, especially in regions with high secondary source contributions. Our global simulations show that $\mathrm{BrC}$ accounts for $21 \%$ of the global mean surface OC concentration, which is typically assumed to be scattering. We find that the global direct radiative effect of $\mathrm{BrC}$ is nearly zero at the top of the atmosphere, and consequently decreases the direct radiative cooling effect of OC by $16 \%$. In addition, the $\mathrm{BrC}$ absorption leads to a general reduction of $\mathrm{NO}_{2}$ photolysis rates, whose maximum decreases occur in Asia up to $-8 \%(-17 \%)$ on an annual (spring) mean basis. The resulting decreases of annual (spring) mean surface ozone concentrations are up to $-6 \%(-13 \%)$ in Asia, indicating a non-negligible effect of $\mathrm{BrC}$ on photochemistry in this region.
\end{abstract}

\section{Introduction}

Carbonaceous aerosols (CAs) are one of the most poorly understood aerosols (Goldstein and Galbally, 2007; Park et al., 2003) and are divided into black carbon (BC) and organic carbon (OC) aerosols. These two types of CAs are emitted together mainly by combustion processes (except for secondary organic carbon, SOC). In the literature, BC is considered as light-absorbing and $\mathrm{OC}$ as light-scattering aerosols until recently. Therefore, the climatic effect of CAs depends on the relative contributions of $\mathrm{BC}$ to CAs. For example, the net direct radiative forcing (DRF) of biomass burning is estimated to be negligible, whereas diesel use causes climate warming, although the first source is larger than the latter with regard to CAs (Forster et al., 2007).

Many field observations and chamber studies recently showed that a certain fraction of OC could absorb solar radiation, especially for ultra-violet wavelengths $(<400 \mathrm{~nm})$ (Alexander et al., 2008; Hecobian et al., 2010; Kirchstetter and Thatcher, 2012; Kirchstetter et al., 2004; Yang et al., 2009). This light-absorbing OC fraction is referred to as brown carbon $(\mathrm{BrC})$ aerosol (Andreae and Gelencser, 2006; Laskin et al., 2015). If $\mathrm{BrC}$ is prevalent, and its DRF is significant, then previous estimates of the DRF of CAs need to be revised.

Recent studies showed that the solar absorption of $\mathrm{BrC}$ is not negligible, and is even comparable to that of $\mathrm{BC}$ (Alexander et al., 2008; Chung et al., 2012; Kirchstetter and Thatcher, 2012). Using residential wood smoke samples, Kirchstetter and Thatcher (2012) calculated that BrC absorption accounts for $14 \%$ of total solar absorption by $\mathrm{CA}$, and even contributes $49 \%$ of solar absorption of CA at wave- 
lengths below $400 \mathrm{~nm}$. Chung et al. (2012) found that OC contributes about $45 \%$ of CA absorption at $520 \mathrm{~nm}$ by analyzing observations at the Gosan site in South Korea. Using aerosol optical property observations at Aerosol Robotic Network (AERONET) sites, Bahadur et al. (2012) estimated that $\mathrm{BrC}$ absorption at $440 \mathrm{~nm}$ is about $40 \%$ of BC absorption at the same wavelength, whereas at $675 \mathrm{~nm}$ it is less than $10 \%$ of BC absorption.

Several efforts have also been made to examine the chemical and physical properties of $\mathrm{BrC}$. Some studies showed that humic-like substances (HULIS) were related to $\mathrm{BrC}$ (Hoffer et al., 2006; Kim and Paulson, 2013; Lukács et al., 2007) based on the high absorption Ångström exponent (AAE) of HULIS in the range of 6-7, indicating that the specific absorption increases substantially towards the shorter wavelengths (Hoffer et al., 2006), although the sources and the dominating chromophores of HULIS have not clearly been revealed yet (Moise et al., 2015; Graber and Rudich, 2006). Alexander et al. (2008) observed individual $\mathrm{BrC}$ spheres in East Asian outflows, and showed that the characteristics of $\mathrm{BrC}$ spheres (AAE of 1.5) were different from those of HULIS and also strongly absorbing. On the other hand, several classes of compounds have been identified as potential contributions to $\mathrm{BrC}$ - nitroaromatic compounds, such as nitrophenols, imidazole-based and other N-heterocyclic compounds, and quinones (Laskin et al., 2015). Furthermore, SOC produced from aromatic species has been found to absorb solar radiation, especially in high- $\mathrm{NO}_{x}$ conditions (Jaoui et al., 2008; Laskin et al., 2015; Lin et al., 2015; Liu et al., 2012; Nakayama et al., 2010, 2013; Yu et al., 2014; Zhong and Jang, 2011).

Even though the chemical composition of $\mathrm{BrC}$ is not clearly understood yet, observations strongly indicate possible important sources of $\mathrm{BrC}$ (Laskin et al., 2015). Using the positive matrix factorisation analysis of absorption at $365 \mathrm{~nm}$ over the southeastern United States in 2007, Hecobian et al. (2010) showed that biomass burning was the most dominant source of $\mathrm{BrC}(55 \%)$, followed by SOC (26-34\%). Many other studies have also suggested biomass burning as the most important BrC source (Chakrabarty et al., 2010; Clarke et al., 2007; Favez et al., 2009; Hoffer et al., 2006; Kirchstetter and Thatcher, 2012; Kirchstetter et al., 2004; McMeeking, 2008; Saleh et al., 2014). Several studies recently proposed $\mathrm{SOC}$ as an additional $\mathrm{BrC}$ source, especially when it is aged in the atmosphere (Bones et al., 2010; Flores et al., 2014; Hawkins et al., 2014; Jaoui et al., 2008; Laskin et al., 2014, 2010; Liu et al., 2014; Nakayama et al., 2010, 2013; Nguyen et al., 2012; Updyke et al., 2012; Zhang et al., 2011; Zhong and Jang, 2011).

Despite the ample observational studies, very few modelling studies have been conducted to simulate global and regional distributions of $\mathrm{BrC}$ and to further quantify its radiative effect (Feng et al., 2013; Jacobson, 2001; Lin et al., 2014; Park et al., 2010; Wang et al., 2014). Jacobson (2001) first assumed $10 \%$ of OC as a solar-absorbing aerosol in a model, and this assumption resulted in an increase of the global DRF by $0.03-0.05 \mathrm{~W} \mathrm{~m}^{-2}$. Park et al. (2010) estimated $\mathrm{BrC}$ concentrations in East Asia using the mass ratio of $\mathrm{BrC}$ to $\mathrm{BC}$, and the resulting annual clear-sky DRF of $\mathrm{BrC}$ over East Asia was $0.05 \mathrm{~W} \mathrm{~m}^{-2}$. Feng et al. (2013) simulated global $\mathrm{BrC}$ concentrations by considering $92 \%$ of $\mathrm{OC}$ from biomass burning and biofuel use as $\mathrm{BrC}$, and estimated $0.09 \mathrm{~W} \mathrm{~m}^{-2}$ for the global clear-sky DRF of BrC. Lin et al. (2014) calculated the DRF of OC by assuming that all of the biomass burning and the biofuel $\mathrm{OC}$ is $\mathrm{BrC}$, and all of the SOC (as a high-absorbing case) as BrC. They estimated the global clear-sky DRF of OC as $-0.20 \mathrm{~W} \mathrm{~m}^{-2}$.

In this study, we estimate global primary $\mathrm{BrC}$ emissions from open burning and biofuel use based on a reported relationship between AAE and modified combustion efficiency (MCE) (McMeeking, 2008). In addition to the primary source above, we also consider SOC produced from aromatic oxidation as a secondary source of $\mathrm{BrC}$ (Hecobian et al., 2010; Jaoui et al., 2008; Lin et al., 2015; Nakayama et al., 2010; Nakayama et al., 2013; Zhong and Jang, 2011). Based on these sources, a global distribution of $\mathrm{BrC}$ concentrations is explicitly simulated for the entire year of 2007 using a global 3-D chemical transport model (GEOS-Chem). We evaluate the model by comparing its results with observations in the United States and all over the globe. Using the best estimate of annual mean $\mathrm{BrC}$ concentrations, we examine the global direct radiative effect (DRE) of $\mathrm{BrC}$ and its effect on photochemistry.

\section{BrC emissions}

In this section, we discuss our method to estimate primary and secondary sources of $\mathrm{BrC}$, and provide explicit global $\mathrm{BrC}$ emissions. The primary and secondary sources include biomass burning and biofuel use, and the production from aromatic volatile organic compounds (VOCs), respectively. Estimated global emissions are used as input for GEOSChem below to explicitly simulate spatial and temporal distributions of $\mathrm{BrC}$ concentrations.

\subsection{Primary sources}

Biomass burning is the largest source of CAs globally (Bond et al., 2004). OC is primarily emitted during the smoldering (low-temperature burning) phase of combustion (Chakrabarty et al., 2010, 2014; Schnaiter et al., 2006), whereas BC is preferentially emitted from the flaming (hightemperature burning) phase. Therefore, $\mathrm{BrC}$ is also emitted largely during the smoldering phase of burning. Here we use the relationship between the burning efficiency and the observed aerosol light absorption to estimate the $\mathrm{BrC}$ emission from biomass burning.

Previous studies have suggested MCE defined in Eq. (1) below to provide quantitative information of burning effi- 
ciencies that can be categorised into flaming versus smoldering combustion (Kaufman et al., 1998; Ward et al., 1992; Ward and Hao, 1991). For example, Reid et al. (2005) used a MCE value of 0.9 to differentiate between flaming (MCE > 0.9) and smoldering combustion (MCE < 0.9).

$\mathrm{MCE}=\frac{\Delta C_{\mathrm{CO}_{2}}}{\Delta C_{\mathrm{CO}_{2}}+\Delta C_{\mathrm{CO}}}$,

where $\Delta C$ is the change in species concentration in fire offgas relative to clean air [molecules $\mathrm{m}^{-3}$ ].

McMeeking (2008) further found a linear relationship between the observed attenuation Ångström exponents and the calculated MCE values from a number of biomass burning samples, as shown in Eq. (2).

$\AA=-17.34 \times \mathrm{MCE}+18.20$,

where $\AA$ is the AAE of biomass burning samples.

The coefficient of determination $\left(R^{2}\right)$ of the relationship in Eq. (2) is 0.39 , so the associated uncertainty appears to be significant. However, the negative relationship between AAE and MCE in Eq. (2) is robust as identified by previous studies (Saleh et al., 2014; Kirchstetter and Thatcher, 2012). For example, absorption of aerosols from biomass burning can be contributed by either $\mathrm{BC}$ or $\mathrm{BrC}$, or both (Moise et al., 2015). As discussed above, the absorption of carbonaceous aerosols is mainly caused by $\mathrm{BC}$ at high-MCE conditions (>0.9); in contrast, the $\mathrm{BC} / \mathrm{CA}$ ratio is almost zero at lowMCE conditions (<0.8) (McMeeking, 2008). Using Eq. (2), we calculate AAE values of 0.86 and 4.3 at MCE values of 1.0 and 0.8 , respectively, and each calculated AAE is in good agreement with the observed BC (0.86) and BrC AAE (5.0) from biomass burning samples measured by Kirchstetter and Thatcher (2012). Saleh et al. (2014) also showed that the BC to $\mathrm{OC}$ ratio (proportional to $\mathrm{MCE}$ ) has a negative relationship with AAE.

In addition, we are able to obtain the $\mathrm{BrC} / \mathrm{BC}$ absorption ratio using AAE. In Appendix A, we present a detailed description of our method for estimating the relationship between the $\mathrm{BrC} / \mathrm{BC}$ absorption ratio and AAE. Our method assumes external mixing, and this assumption can cause uncertainties when particles are internally mixed (such as the coating effect). For uncertainty analysis, we calculate three $\mathrm{BrC} / \mathrm{BC}$ absorption cases as shown in Fig. 1, which shows the estimated $\mathrm{BrC} / \mathrm{BC}$ absorption ratio at $550 \mathrm{~nm}$ as a function of MCE. Different lines indicate different AAEs of $\mathrm{BC}$ and $\mathrm{BrC}$ according to the Table 1 of Kirchstetter and Thatcher (2012). They calculated BC AAE and BrC AAE using 115 wood smoke samples. For the calculation of $\mathrm{BrC}$ AAE, BC AAE had to be decided, and they assumed three different BC AAEs $(0.86,1.00,1.15)$ based on their smoke samples and previous studies. Resulting BrC AAEs were $5.00,5.48$, and 6.19. We conduct three simulations according to the Fig. 1, as described later in this section. For highMCE conditions $(>0.95)$, the $\mathrm{BrC}$ contribution to the $\mathrm{CA}$

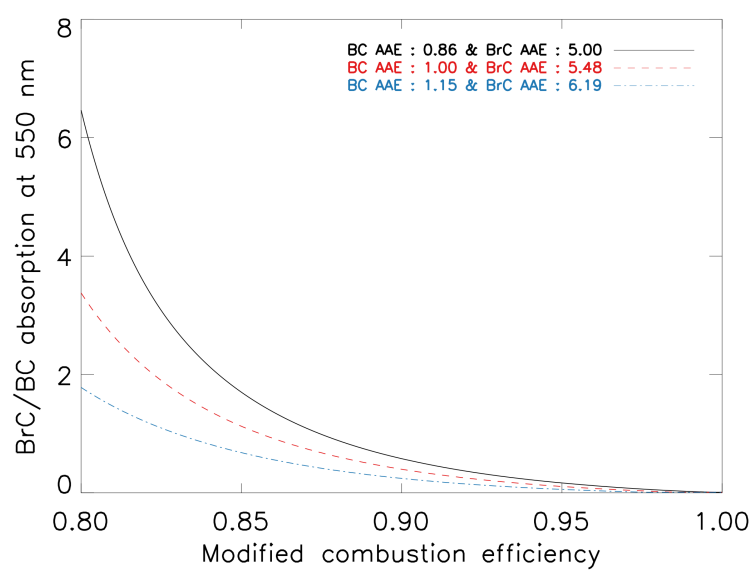

Figure 1. Estimated absorption ratios of $\mathrm{BrC}$ to $\mathrm{BC}$ at $550 \mathrm{~nm}$ as a function of MCE. We assume that the CA absorption is only contributed by $\mathrm{BC}$ and $\mathrm{BrC}$ absorption. Black solid line indicates case 1 , red dashed line represents case 2 , and blue dotted line shows case 3 .

absorption is negligible, whereas it becomes significant for low-MCE conditions $(<0.85)$.

We calculate the MCE of biomass burning based on the Fire Inventory from NCAR (National Center for Atmospheric Research) (FINN) (Wiedinmyer et al., 2011) with vegetation-dependent emission factors of $\mathrm{CO}_{2}$ and $\mathrm{CO}$ using Eq. (3) as follows:

$$
\begin{aligned}
\mathrm{MCE} & =\frac{\Delta C_{\mathrm{CO}_{2}}}{\Delta C_{\mathrm{CO}_{2}}+\Delta C_{\mathrm{CO}}} \\
& =\frac{\mathrm{EF}_{\mathrm{CO}_{2}} / \mathrm{MW}_{\mathrm{CO}_{2}}}{\mathrm{EF}_{\mathrm{CO}_{2}} / \mathrm{MW}_{\mathrm{CO}_{2}}+\mathrm{EF}_{\mathrm{CO}} / \mathrm{MW}_{\mathrm{CO}}},
\end{aligned}
$$

where EF is the emission factor [g-species kg-dry matter ${ }^{-1}$ ] and MW is the molecular weight [g-species mole $\left.{ }^{-1}\right]$.

Finally, mass absorption efficiency (MAE), which is used for converting light absorption to mass concentration, is needed to obtain the $\mathrm{BrC} / \mathrm{BC}$ mass ratio from the $\mathrm{BrC} / \mathrm{BC}$ absorption ratio. For the fresh $\mathrm{BC} \mathrm{MAE}$ at $550 \mathrm{~nm}$, we use the value of $7.5 \mathrm{~m}^{2} \mathrm{~g}^{-1}$ recommended by Bond and Bergstrom (2006) (Nakayama et al., 2013; Park et al., 2010). For $\mathrm{BrC}$, a large range of MAE values $\left(0.09-4.1 \mathrm{~m}^{2} \mathrm{~g}^{-1}\right.$ at $550 \pm 30 \mathrm{~nm}$ ) has been reported (Alexander et al., 2008; Cheng et al., 2011; Chung et al., 2012; Clarke et al., 2007; Favez et al., 2009; Hecobian et al., 2010; Hoffer et al., 2006; Kirchstetter et al., 2004; McMeeking, 2008; Yang et al., 2009). The highest MAE $\left(3.6-4.1 \mathrm{~m}^{2} \mathrm{~g}^{-1}\right.$ at $550 \mathrm{~nm}$ ) was observed by Alexander et al. (2008), who used transmission electron microscopy to identify the optical properties of individual $\mathrm{BrC}$ particles in the atmosphere. Generally, low MAEs were reported when analyzing water-soluble organic carbon (WSOC) from water extracts (Cheng et al., 2011; Hecobian et al., 2010; Srinivas and Sarin, 2014), indicating that WSOC may include both BrC and colourless OC. Intermediate MAEs mostly came from optical measurements 
Table 1. Emission factors (EFs) and calculated parameters used for primary BrC emission estimates. Biomass burning emission is classified for six vegetation types based on the FINN inventory. Here $\mathrm{BrC} / \mathrm{OC}$ is the mass ratio of BrC to OC emitted from biomass burning and biofuel use.

\begin{tabular}{|c|c|c|c|c|c|c|c|c|}
\hline \multirow{2}{*}{$\begin{array}{l}\text { Source type } \\
\text { Biomass burning }\end{array}$} & \multirow[t]{2}{*}{$\mathrm{CO}_{2} \mathrm{EF}\left[\mathrm{g} \mathrm{kg}^{-1}\right]$} & \multirow[t]{2}{*}{$\mathrm{CO} \mathrm{EF}\left[\mathrm{g} \mathrm{kg}^{-1}\right]$} & \multirow[t]{2}{*}{ MCE } & \multirow[t]{2}{*}{$\mathrm{OC} \mathrm{EF}\left[\mathrm{g} \mathrm{kg}^{-1}\right]$} & \multirow[t]{2}{*}{$\mathrm{BC}$ EF $\left[\mathrm{g} \mathrm{kg}^{-1}\right]$} & \multicolumn{3}{|c|}{$\mathrm{BrC} / \mathrm{OC}$} \\
\hline & & & & & & case 1 & case2 & case3 \\
\hline Boreal forest & 1514 & 118 & 0.891 & 7.8 & 0.20 & 0.135 & 0.093 & 0.057 \\
\hline Cropland & 1537 & 111 & 0.898 & 3.3 & 0.69 & 0.946 & 0.652 & 0.400 \\
\hline Savanna/grassland & 1692 & 59 & 0.948 & 2.6 & 0.37 & 0.189 & 0.123 & 0.067 \\
\hline Temperate forest & 1630 & 102 & 0.910 & 9.2 & 0.56 & 0.211 & 0.145 & 0.088 \\
\hline Tropical forest & 1643 & 92 & 0.919 & 4.7 & 0.52 & 0.312 & 0.213 & 0.128 \\
\hline Woody savannah/shrubland & 1716 & 68 & 0.941 & 6.6 & 0.50 & 0.123 & 0.081 & 0.046 \\
\hline Biofuel* $^{*}$ & & & & & & 0.663 & 0.452 & 0.271 \\
\hline
\end{tabular}

* Detailed information is given in Table 2 .

(Chung et al., 2012; Favez et al., 2009; Yang et al., 2009). For the primary $\mathrm{BrC}$ MAE, we use $1.0 \mathrm{~m}^{2} \mathrm{~g}^{-1}$ at $550 \mathrm{~nm}$ based on McMeeking (2008), who conducted a number of MAE measurements of biomass burning samples $(\sim 30$ unique fuels tested in $\sim 230$ burns) using both filter-based and opticalbased methods. In brief, we use the MAE values of 7.5 and $1.0 \mathrm{~m}^{2} \mathrm{~g}^{-1}$ at $550 \mathrm{~nm}$ for $\mathrm{BC}$ and primary $\mathrm{BrC}$, respectively. But at a shorter wavelength, a higher MAE value was used for primary $\mathrm{BrC}$ (e.g. $5.3 \mathrm{~m}^{2} \mathrm{~g}^{-1}$ at $365 \mathrm{~nm}$ as discussed in Sect. 4).

Using the results in Fig. 1 with Eq. (3), we calculate the $\mathrm{EF}$ (mass) ratio of $\mathrm{BrC}$ to $\mathrm{OC}$ as summarised in Table 1. The $\mathrm{EF}$ ratio of $\mathrm{BrC}$ to $\mathrm{OC}$ differs for each vegetation type and assumed BC AAE (0.86-1.15). Among different vegetation types, cropland burning shows the highest $\mathrm{BrC}$ to $\mathrm{OC}$ mass ratio, driven by the low MCE and the highest ratio of $\mathrm{BC}$ to $\mathrm{OC} \mathrm{EF}$. Because we calculate the $\mathrm{BrC}$ to $\mathrm{OC} \mathrm{EF}$ ratio by multiplying the $\mathrm{BrC}$ to $\mathrm{BC} \mathrm{EF}$ ratio by the $\mathrm{BC}$ to $\mathrm{OC}$ ratio, the high $\mathrm{BC}$ to $\mathrm{OC}$ ratio can lead to a high $\mathrm{BrC}$ to $\mathrm{OC}$ ratio. Although Table 1 shows the highest $\mathrm{BrC} / \mathrm{OC}$ ratio from cropland burning, its contribution to the global $\mathrm{BrC}$ emission is small because the $\mathrm{OC}$ emission from the cropland is the lowest (Wiedinmyer et al., 2011). Instead, the tropical forest burning is the highest, and the resulting total $\mathrm{BrC}$ emission from biomass burning is $3.9 \pm 1.7 \mathrm{TgC}^{-1}$, which contributes about $17 \pm 7 \%$ of total OC emission from biomass burning (22.7 $\mathrm{TgC} \mathrm{yr}^{-1}$ ) (Wiedinmyer et al., 2011).

Our method of estimating $\mathrm{BrC}$ emissions from biofuel use is similar to that of estimating emissions from biomass burning. We estimate $\mathrm{BrC} / \mathrm{OC}$ ratio using the $\mathrm{MCE}$ and $\mathrm{BC}$ to OC ratio in the same way as the biomass burning estimates. The only difference is that the biofuel emission of each sector is not known (the biomass burning emission is known for each vegetation type). Therefore, we first estimate OC biofuel emissions from each biofuel category with the information given by previous studies (Bond et al., 2007, 2004; Fernandes et al., 2007). Because there is no clear evidence that $\mathrm{BrC}$ is emitted by dung, charcoal, and the industrial sector, here we consider only fuelwood and agricultural residue as $\mathrm{BrC}$ sources. Fuelwood burning is the largest contributor to biofuel $\mathrm{BrC}$ emission. Our estimate of $\mathrm{BrC} / \mathrm{OC}$ mass ratio is $0.271-0.663$ from biofuel use. Overall results are summarised in Table 2. Note that base year of Table 2 is 2000 because previous studies reported their values based on 2000. We scale up the emission for 2007 as described in Sect. 3.2. Resulting $\mathrm{BrC}$ emission from biofuel use is $3.0 \pm 1.3 \mathrm{TgC} \mathrm{yr}^{-1}$, which is comparable to $\mathrm{BrC}$ emission from biomass burning.

\subsection{Secondary source}

We consider SOC as a source of $\mathrm{BrC}$ in the model based on the observed optical characteristic of SOC, depending on its chemical formation, as follows: (1) anthropogenic (aromatic) SOCs tend to absorb solar radiation more efficiently than biogenic SOCs (Jacobson, 1999; Nakayama et al., 2010; Zhong and Jang, 2011; Zhong et al., 2012); (2) the solar absorption efficiency increases as SOCs undergo atmospheric aging processes (Bones et al., 2010; Lambe et al., 2013; Laskin et al., 2015, 2010; Updyke et al., 2012); (3) SOCs formed in inorganic seeds have a darker colour than others (Jaoui et al., 2008; Nakayama et al., 2013; Zhong and Jang, 2011; Zhong et al., 2012); moreover, SOCs become darker when they undergo aging in the presence of nitrogen-containing inorganic gases and aerosols (Bones et al., 2010; Laskin et al., 2010; Liu et al., 2012).

Among those factors, the first two are more important than the last. For example, the absorbance of aged biogenic SOCs produced in inorganic seeds is much lower than that of fresh anthropogenic SOCs under no-seed conditions (Zhong and Jang, 2011). Furthermore, Lambe et al. (2013) suggested that the effect of $\mathrm{NO}_{x}$ on SOC light absorption is small under typical ranges of $\mathrm{VOC} / \mathrm{NO}_{x}$. Therefore, here we consider the first two factors for $\mathrm{BrC}$ simulations in the model. We assume anthropogenic (aromatic) SOCs with high atmospheric aging as $\mathrm{BrC}$ in the model. Atmospheric aging is calculated using the volatility basis set (VBS) approach with six bins in the model (Jo et al., 2013), where SOC concentrations of the first two bins are considered as $\mathrm{BrC}$. However, we note that 
Table 2. Global biofuel consumption estimates, EFs of OC, and OC biofuel emission estimates for each biofuel category. Base year is 2000.

\begin{tabular}{|c|c|c|c|c|c|c|}
\hline & Fuelwood & $\begin{array}{r}\text { Crop } \\
\text { residues }\end{array}$ & Dung & Charcoal & Industrial & Total \\
\hline Biofuel consumption $^{\mathrm{a}}[\mathrm{Tg}]$ & 1351 & 495 & 75 & 39 & 498 & 2457 \\
\hline $\mathrm{EF}\left[\mathrm{g} \mathrm{kg}^{-1}\right]^{\mathrm{b}}$ & $2.97^{\mathrm{c}}$ & 3.3 & 1.8 & 1.3 & $0.91^{\mathrm{c}}$ & 2.6 \\
\hline OC emission $[\mathrm{Gg}]$ & 4010.3 & 1633.5 & 135 & 50.7 & 453.6 & $6281^{\mathrm{d}}$ \\
\hline \multirow[t]{3}{*}{$\mathrm{BrC} / \mathrm{OC}$} & 0.653 & 0.946 & 0.000 & 0.000 & 0.000 & \\
\hline & 0.442 & 0.652 & 0.000 & 0.000 & 0.000 & \\
\hline & 0.261 & 0.400 & 0.000 & 0.000 & 0.000 & \\
\hline
\end{tabular}

${ }^{a}$ From Fernandes et al. (2007). ${ }^{\mathrm{b}}$ From Bond et al. (2004). ${ }^{\mathrm{c}}$ Global mean value is estimated from Bond et al. (2004). ${ }^{\mathrm{d}}$ From GEOS-Chem biofuel OC inventory (carbon_200909) by Bond et al. (2007).

some brown SOCs can be bleached when they undergo photodissociation (Zhong and Jang, 2011; Sareen et al., 2013). Furthermore, browning reactions can be accelerated by cloud and fog processing of aerosols (Moise et al., 2015), which are not considered in this study. More detailed treatments of the chemical aging of $\mathrm{BrC}$ are needed in future $\mathrm{BrC}$ models.

$\mathrm{BrC}$ from anthropogenic SOC has different optical properties (i.e. MAE, imaginary refractive index) compared with $\mathrm{BrC}$ from wood burning. Therefore, we apply different optical parameters for the model evaluation (Sect. 4) such as $5.3 \mathrm{~m}^{2} \mathrm{~g}^{-1}$ (McMeeking, 2008) for primary $\mathrm{BrC}$ and $1.5 \mathrm{~m}^{2} \mathrm{~g}^{-1}$ (Nakayama et al., 2010) for secondary $\mathrm{BrC}$ at $365 \mathrm{~nm}$ (note that the MAE of primary $\mathrm{BrC}$ at $550 \mathrm{~nm}$ is $1.0 \mathrm{~m}^{2} \mathrm{~g}^{-1}$ as discussed in Sect. 2.1). The estimated annual

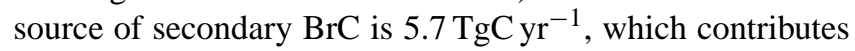
$45 \%$ of total $\mathrm{BrC}$ sources.

\section{Model description}

\subsection{General}

We use the GEOS-Chem (version 9.1.2) global 3-D chemical transport model (Bey et al., 2001) to simulate BrC for 2007. The model is driven by Modern Era Retrospective-analysis for Research and Applications (MERRA) assimilated meteorological data from the Global Modelling and Assimilation Office Goddard Earth Observing System (Rienecker et al., 2011). The data include winds, precipitation, temperature, boundary layer height, and other meteorological variables at $0.5^{\circ} \times 0.667^{\circ}$ horizontal resolutions, but are degraded to $2^{\circ} \times 2.5^{\circ}$ for computational efficiency.

We conduct a fully coupled oxidant-aerosol simulation, including $\mathrm{SO}_{4}^{2-}-\mathrm{NO}_{3}^{-}-\mathrm{NH}_{4}^{+}$, soil dust, and sea salt aerosols. The simulation of carbonaceous aerosols in the GEOS-Chem is based on Park et al. (2003, 2006). The model carries BC and POC (primary organic carbon), with a hydrophobic and hydrophilic fraction for each. We assume that $80 \%$ of BC and $50 \%$ of POC are emitted as hydrophobic (the rest is hydrophilic), then hydrophobic aerosols become hydrophilic with an $e$-folding time of 1.15 days (Cooke et al., 1999). For the SOC simulation, we use the VBS approach based on Jo et al. (2013). All SOC is considered as hydrophilic, and more details are described in previous SOC studies (Chung and Seinfeld, 2002; Henze and Seinfeld, 2006; Henze et al., 2008; Jo et al., 2013; Liao et al., 2007). Note that we consider only the carbon mass of $\mathrm{OC}$ including $\mathrm{BrC}$ as discussed below, to avoid uncertainties involved in converting organic carbon to organic matter concentrations, which is typically done by multiplying a constant ratio (e.g. 1.4-2.1) (Aiken et al., 2008; Turpin and Lim, 2001).

\subsection{Emissions}

We use fossil fuel and biofuel emissions of CAs for 2000 with no monthly variations from Bond et al. (2007). However, domestic wood burning for heating has strong seasonal dependency, so we additionally use the Monitoring Atmospheric Composition and Climate/City Zen (MACCity) emission inventory (Diehl et al., 2012; Granier et al., 2011) to obtain seasonal variations of global biofuel emissions and to scale up for 2007. For this, we divide the whole globe into regions with similar seasonality according to the Atmospheric Chemistry and Climate Model Intercomparison Project (ACCMIP) (Lamarque et al., 2010), which is the basis of the MACCity inventory. We apply the annual trend of each ACCMIP region to the emissions from Bond et al. (2007). The emissions for each region and trends are listed in Tables S1 and S2 in the Supplement.

We use biomass burning emissions from FINN version 1.0 (Wiedinmyer et al., 2011), which provides global daily estimates of trace gases and aerosols at $1 \mathrm{~km}$ horizontal resolution for 2002-2012 (http://bai.acd.ucar.edu/Data/fire/). However, the FINN version 1.0 inventory does not include aromatic VOCs (benzene, toluene, and xylene), the emissions of which are estimated by multiplying dry burned matter by emission factors from Akagi et al. (2011) and Andreae and Merlet (2001). 


\section{Model evaluation}

We conduct a model evaluation using the observed light absorption of WSOC measured by Hecobian et al. (2010) and Zhang et al. $(2011,2013)$ in the United States. The model evaluation allows us not only to validate simulated $\mathrm{BrC}$ concentrations but also to examine each source contribution to $\mathrm{BrC}$ in the United States. We also use the global single scattering albedo (SSA) observations from the AERONET to evaluate the effect of including $\mathrm{BrC}$ on light absorption by aerosols over the globe.

\subsection{United States}

Prior to evaluating $\mathrm{BrC}$ simulations, we first focus on $\mathrm{BC}$ and $\mathrm{OC}$ aerosols in the model to examine the general model performance in simulating carbonaceous aerosol concentrations in the United States. We use BC and OC observations from the Interagency Monitoring of Protected Visual Environments (IMPROVE) network for 2007 (Malm et al., 1994). Most sites were situated in rural regions, measuring background concentrations of $\mathrm{BC}$ and $\mathrm{OC}$. The data were available every 3 days; more than 20000 samples were used for our comparison. For comparison with the model results, we computed the observed monthly mean concentrations of $\mathrm{BC}$ and OC averaged on the $2^{\circ} \times 2.5^{\circ}$ model grid.

Figure 2 shows scatter plot comparisons of the observed and simulated monthly mean $\mathrm{BC}$ and $\mathrm{OC}$ concentrations in the United States. The model slightly underestimates both $\mathrm{BC}$ and $\mathrm{OC}$ over the United States, consistent with similar comparisons in Huang et al. (2013). We calculate the annual mean concentrations of the model using the simulated values of model grid boxes corresponding to the IMPROVE network sites. The simulated annual mean BC concentration is $0.22 \mu \mathrm{gC} \mathrm{m}^{-3}$, which is $12 \%$ lower than the observed mean value $\left(0.25 \mu \mathrm{gC} \mathrm{m}^{-3}\right)$. However, the bias in the model is larger for OC by $30 \%\left(1.16\right.$ and $0.81 \mu \mathrm{gC} \mathrm{m}{ }^{-3}$ for observed and simulated OC concentrations, respectively), which is additionally due to the underestimation of SOC in the model (Jo et al., 2013). This low bias for SOC can be reflected in the simulated $\mathrm{BrC}$ concentrations, which is discussed later in this section.

We use the light absorption observations of WSOC measured using a UV-Vis spectrophotometer and long-path absorption cell by Hecobian et al. (2010), and compare them with the light absorption by $\mathrm{BrC}$ in the model. Absorption coefficients of WSOC at $365 \mathrm{~nm}$ were measured at 15 sites in the southeastern United States in 2007. Among them, eight sites are in urban areas, and the others are in rural regions. Detailed descriptions of the measurements are available in Hecobian et al. (2010).

Because light absorption observations are measured only for water-soluble fractions of OC, and do not include waterinsoluble components, we separate $\mathrm{BrC}$ in the model into water-soluble and water-insoluble components. The model
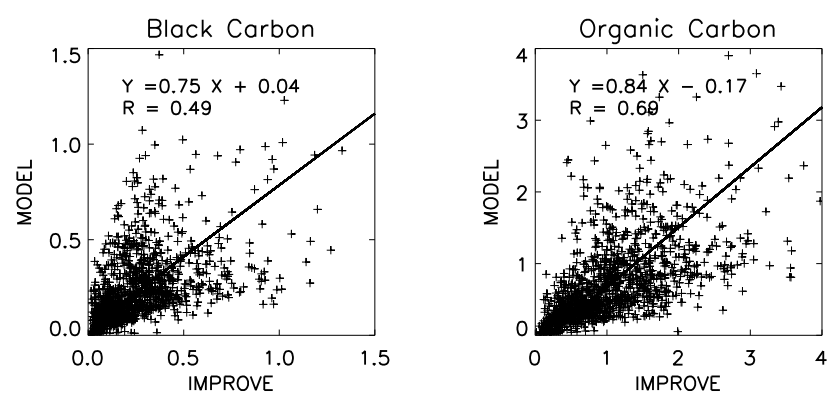

Figure 2. Scatter plot of simulated versus observed BC concentrations (left) and OC concentrations (right). Unit is $\mu \mathrm{gC} \mathrm{m}^{-3}$. Values are monthly means for 2007. Regression equations and correlations are shown inset. Regression is computed with reduced major axis (RMA) method.

divides $\mathrm{OC}$ (or $\mathrm{BrC}$ ) into hydrophilic and hydrophobic components. For the comparison, we do not use the simulated hydrophilic fraction, but instead use an observed WSOC / OC ratio because the assumed division of hydrophobic and hydrophilic fractions of OC and their conversion can be applicable in a global sense, but in a regional sense it may cause a significant discrepancy. For example, the observed watersoluble fraction of the total OC is generally low (of the order of $25 \%$ ) in the Los Angeles basin (Zhang et al., 2013); on the other hand, the model simulates a high water-soluble fraction of the total OC (63-74\%) in this region. For this reason, we decided to use the observed WSOC / OC ratio for the evaluations. In the southeastern United States, the observed WSOC / OC ratio is about 0.58 (Weber et al., 2007; Zhang et al., 2013), which is also used to estimate the water-soluble $\mathrm{BrC}$ concentrations from the total $\mathrm{BrC}$ concentrations in the model.

Because the model simulates a mass concentration of $\mathrm{BrC}$, a conversion from the mass concentration to light absorption is carried out by multiplying MAE values. For BrC from wood burning, we use the MAE value of $5.3 \mathrm{~m}^{2} \mathrm{~g}^{-1}$ at $365 \mathrm{~nm}$ measured by McMeeking (2008) in order to retain the consistency between our emission estimates and the evaluation. For BrC from SOC, we select the MAE of $1.5 \mathrm{~m}^{2} \mathrm{~g}^{-1}$ at $365 \mathrm{~nm}$ calculated by Nakayama et al. (2010) (see Fig. 4 in their paper).

Figure 3 shows monthly mean simulated and observed light absorption coefficients of $\mathrm{BrC}$ at $365 \mathrm{~nm}$ averaged over all sites in the southeastern United States for 2007. Black circles and coloured bars indicate the observed and simulated $\mathrm{BrC}$ absorption at $365 \mathrm{~nm}$, respectively, and different colours in the bar show contributions from different sources. Each panel represents a different model simulation with each case of AAE selections as shown in Fig. 1 and Table 1.

In winter months (November through March), the observed light absorptions were generally high and reached a peak in March. These high absorptions were highly correlated with levoglucosan, which is a marker for biomass burn- 


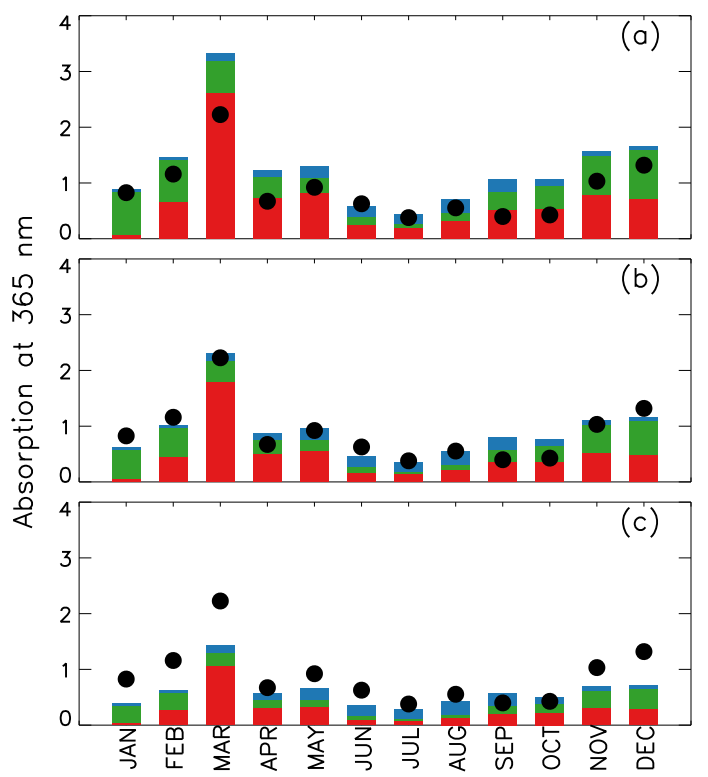

Figure 3. Simulated versus observed monthly mean light absorption at $365 \mathrm{~nm}$ by water-soluble $\mathrm{BrC}$ over the southeastern United States in 2007. Unit is $\mathrm{Mm}^{-1}$. Black circles denote observations, and bar graphs indicate model results for each source: biomass burning (red), biofuel (green), and SOC (blue). Each panel shows the comparisons with different emission estimate cases - (a) case 1, (b) case 2, and (c) case 3 .

ing (Hecobian et al., 2010). During the summer, the observed light absorptions decreased substantially.

The model generally captures the observed seasonal variation with high absorption in the winter, having a peak in March and low absorption in the summer ( $R$ of 0.93). On an annual mean basis, we find that the model is too high at $46 \%$ for case 1 , and is too low at $-31 \%$ for case 3 , relative to the observations. The model for case 2 is in best agreement with the observations (4\%) on an annual mean basis.

The BrC source contribution in the model is similar to the observed source contribution. Hecobian et al. (2010) showed that biomass burning was the main contributor for the winter season, whereas the SOC contribution increased during the summer season. The simulated seasonal variation is consistent with the observation, as shown in Fig. 3. The annual mass contribution of SOC to $\mathrm{BrC}$ is $38 \%$ (in case 2), which is in good agreement with the observed contribution of $32 \%$ (Hecobian et al., 2010). Based on the results in Fig. 3, the model for the case 2 yields best estimates of $\mathrm{BrC}$ emissions.

In addition to the observation by Hecobian et al. (2010), we use the light absorption observations by Zhang et al. (2011, 2013). Measurements were carried out in Atlanta, GA $\left(33.778427^{\circ} \mathrm{N}, 84.396181^{\circ} \mathrm{W}\right)$, Pasadena, CA $\left(34.140528^{\circ} \mathrm{N}, 118.122455^{\circ} \mathrm{W}\right)$, and Riverside, CA $\left(33.97185^{\circ} \mathrm{N}, 117.32266^{\circ} \mathrm{W}\right)$ for a month or less. As discussed above, we apply the observed WSOC / OC ratio to the model $\mathrm{BrC}$ concentrations: $26 \%$ for the Los Angeles basin

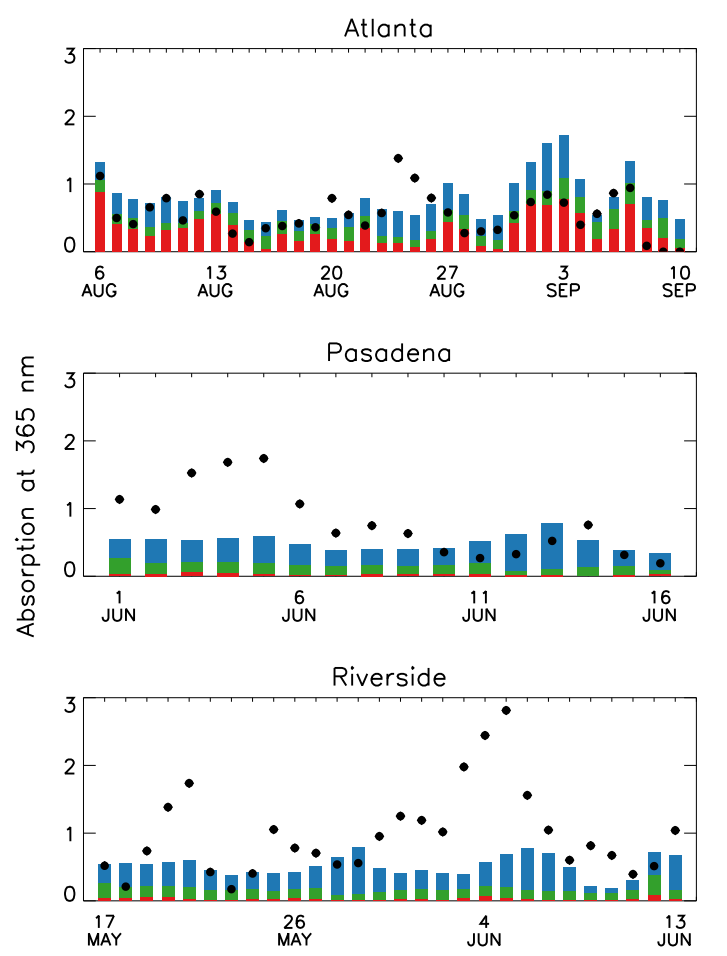

Figure 4. Simulated versus observed daily mean light absorption at $365 \mathrm{~nm}$ by water-soluble $\mathrm{BrC}$ over the United States in 2010; unit is $\mathrm{Mm}^{-1}$. Black circles denote observations and bar graphs indicate model results for each source - biomass burning (red), biofuel (green), and SOC (blue).

(Pasadena and Riverside) (Zhang et al., 2013) and 58\% for Atlanta (Weber et al., 2007; Zhang et al., 2013).

Figure 4 shows the daily mean observed and simulated light absorption coefficients from the best model (case 2) for Atlanta, Pasadena, and Riverside for 2010. The upper panel shows the comparison of the observed versus simulated light absorption for Atlanta. The highest observed daily absorption occurred on 24 August, but the model fails to reproduce it. Furthermore, the model generally overestimates the observed absorption by $44 \%$, and the large discrepancies mainly occur in September. This large discrepancy in September is similar to the result shown in Fig. 3b for 2007.

The middle and lower panels show the comparisons at the Los Angeles basin sites in May and June. The observed mean light absorptions at these sites $\left(0.81\right.$ and $0.98 \mathrm{Mm}^{-1}$ for Pasadena and Riverside, respectively) are higher than the observed mean light absorption $\left(0.56 \mathrm{Mm}^{-1}\right)$ for Atlanta. However, the model underestimates the observations by $38 \%$ (Pasadena) and $48 \%$ (Riverside). Zhang et al. (2013) showed that the main sources of $\mathrm{BrC}$ at these sites were $\mathrm{SOC}$ from anthropogenic emissions. The model also shows a high contribution ( $85 \%$ ) of the secondary source to the total $\mathrm{BrC}$ mass concentrations, but the magnitudes are generally lower than the observations, and this low bias is likely related to the un- 
derestimation of the simulated SOC concentrations using the 1-D VBS (Jo et al., 2013).

We find from the model evaluation over the United States that the model generally captures the observed mean absorption and its seasonal variability in the region where primary sources are dominant. On the other hand, the model underestimates the observed mean absorption in the region with the dominant secondary sources. The low bias is partly explained by the SOC underestimation in the model. However, the underestimations of BrC from SOC (38-48\%) are higher than those of SOC (18\%), indicating the importance of additional secondary BrC sources that we did not include in the model.

A MAE value for secondary $\mathrm{BrC}$ could be another possible reason for the bias in the model. Although chamber studies suggested weak absorbing characteristics of BrC from SOC (Nakayama et al., 2010, 2013; Zhong and Jang, 2011), some field observations speculated the existence of strongly absorbing BrC from SOC (Alexander et al., 2008; Chung et al., 2012). For example, applying the MAE value of $3.5 \mathrm{~m}^{2} \mathrm{~g}^{-1}$ at $365 \mathrm{~nm}$ (a half of the MAE at $365 \mathrm{~nm}$ from Alexander et al., 2008) for secondary BrC yields a similar mean absorption value to the observation over LA basin. Extensive observations of optical characteristics of $\mathrm{BrC}$ depending on the formation mechanisms would be needed to reduce the associated uncertainties and to improve the model.

\subsection{Evaluation against global AERONET observations}

No global observation of $\mathrm{BrC}$ is available yet. Here we use the observed SSA at AERONET sites to evaluate the model by focusing on the effect of $\mathrm{BrC}$ on the simulated aerosol absorption. We also use observed aerosol optical depth (AOD) to evaluate the model capability to simulate aerosol mass concentrations.

For comparisons of AOD and SSA between the model and observations, we use FlexAOD (http://pumpkin.aquila.infn. it/flexaod/), which calculates AOD and SSA using simulated aerosol mass concentrations from GEOS-Chem with the Mie algorithm (Mischenko et al., 2002; Curci et al., 2015).

For optical properties of $\mathrm{BrC}$, we use imaginary refractive indices of BrC from McMeeking (2008) for wood burning sources, and from Nakayama et al. (2010) for SOC sources. Detailed description of the values used in AOD and SSA calculation are provided in Sect. 6, where we discuss the DRE of $\mathrm{BrC}$.

Figure 5 shows comparisons of monthly mean simulated versus observed AOD at $500 \mathrm{~nm}$ and SSA at $440 \mathrm{~nm}$. We find that the model captures the observed AOD quite well with a regression slope of 0.86 and a $R$ of 0.88 . However, the model tends to overestimate the observed SSA, implying that the simulated aerosol concentrations appear to have too large a fraction of scattering aerosols. We find that the inclusion of $\mathrm{BrC}$ in the model reduces the high bias of simulated SSA by 33 and $23 \%$ (lower left and lower right panel of Fig. 5), indicating a considerable contribution of $\mathrm{BrC}$ to aerosol ab-

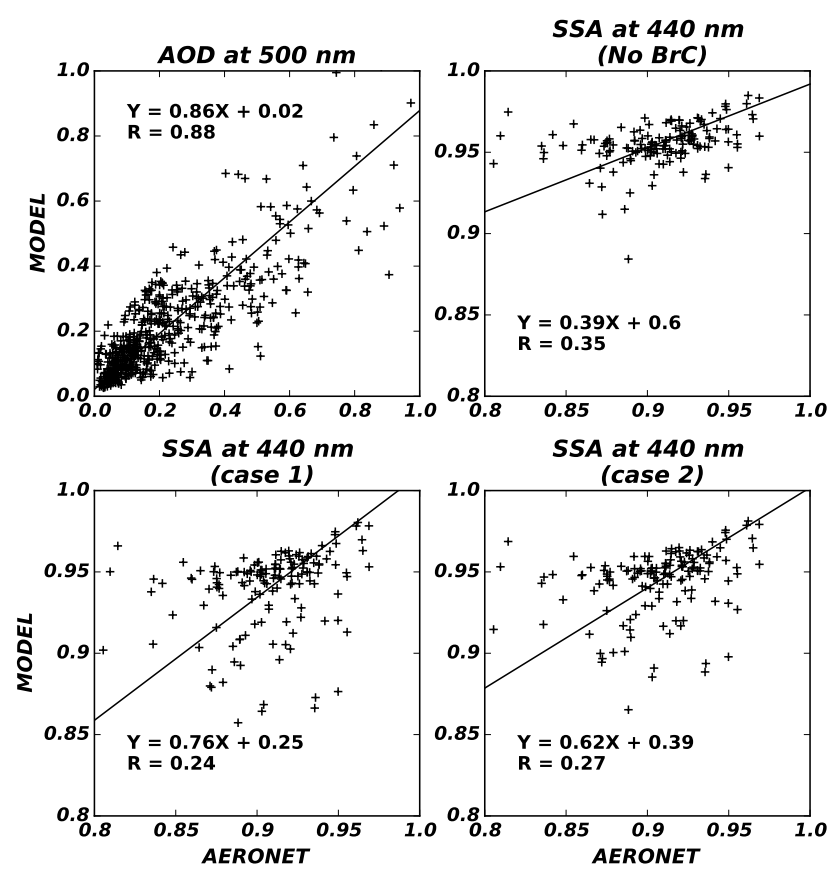

Figure 5. Scatter plots of simulated versus observed AOD at $500 \mathrm{~nm}$ (upper left), SSA at $440 \mathrm{~nm}$ without $\mathrm{BrC}$ (upper right), SSA at $440 \mathrm{~nm}$ with $\mathrm{BrC}$ of case 1 (lower left), and SSA at $440 \mathrm{~nm}$ with $\mathrm{BrC}$ of case 2 (lower right) for 2007. Reduced major axis regression is shown along with the regression equation and $R$. Each point indicates monthly averaged AOD or SSA when the number of observation is greater than 10 days.

sorption. Although the statistics suggest a greater improvement with case 1 in terms of the bias, simulated SSA values at sites in Africa with high $\mathrm{BrC}$ concentrations, are too low apart from the regression line (discrepancy $>0.1$ ). This result also supports our selection of case 2 as the best model for BrC emission estimates.

Despite a decrease of simulated SSA with $\mathrm{BrC}$, the model is still too high relative to the observations. The overestimation might be partly caused by the underestimation of BC emissions from biomass burning (Bond et al., 2013). This is also supported by the fact that the discrepancy gets larger for biomass burning regions, where a difference between the model and AERONET SSA is $40 \%$ higher than that in regions with high anthropogenic emissions. Emission factors of BC used in this study are $0.2-0.69 \mathrm{~g} \mathrm{~kg}^{-1}$ (Wiedinmyer et al., 2011), which are lower than the value of $1 \mathrm{~g} \mathrm{~kg}^{-1}$ used by Chin et al. (2009), who found no significant bias in their model compared with the AERONET SSA. Lin et al. (2014) also reported a small bias in their model compared with AERONET SSA using 4.7 $\mathrm{Tg} \mathrm{yr}^{-1}$ of global annual biomass burning $\mathrm{BC}$ emissions, which is about 2 times higher than $2.2 \mathrm{Tg} \mathrm{yr}^{-1}$ of this study.

In addition to the biomass burning emission of $\mathrm{BC}$, the anthropogenic emission of $\mathrm{BC}$ could also contribute to the simulated SSA bias. Cohen and Wang (2014) showed that 

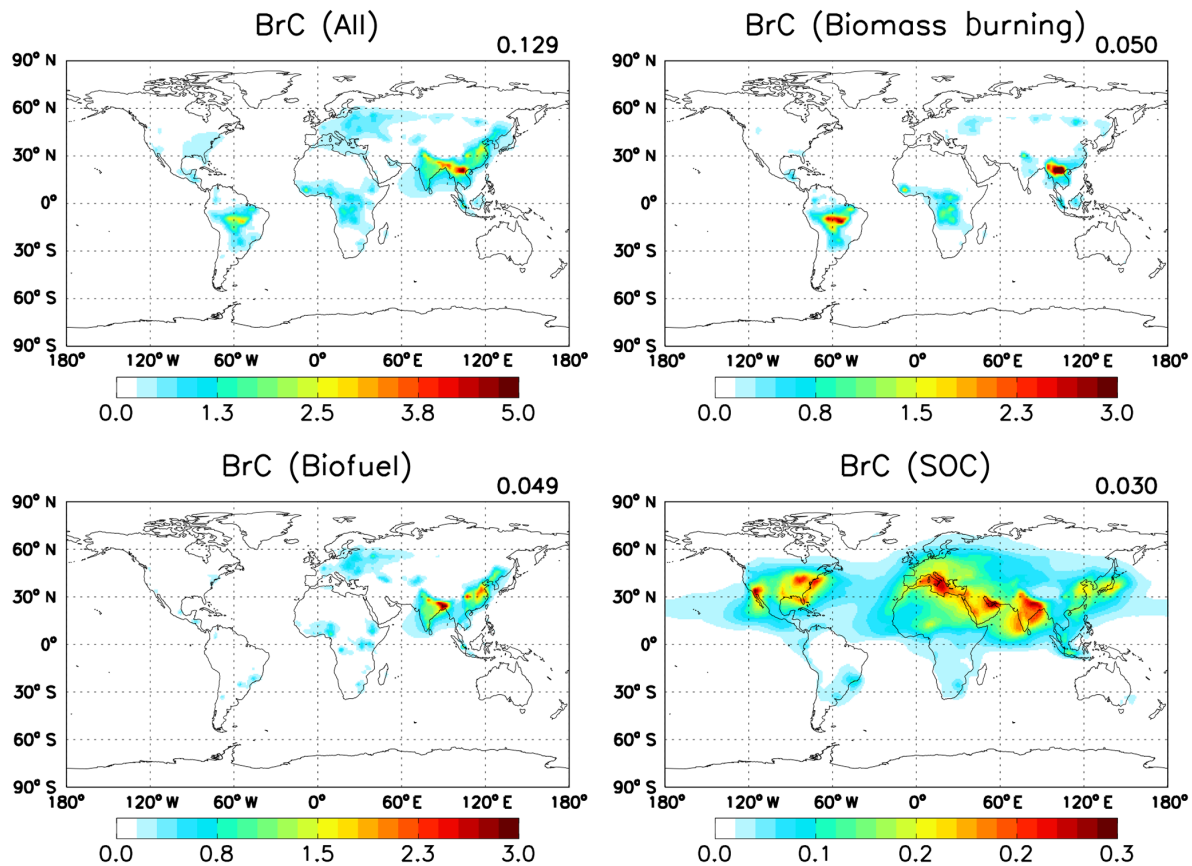

Figure 6. Annual surface map of total $\mathrm{BrC}$ (top left) and $\mathrm{BrC}$ from three source categories: biomass burning (top right), biofuel (bottom left), and SOC (bottom right). Mean values are presented in the upper right corner of each panel. Unit is $\mu g \mathrm{~g} \mathrm{~m}^{-3}$.

a global top-down emission of $\mathrm{BC}$ is twice as large as the bottom-up estimates of $\mathrm{BC}$ based on the Kalman filter approach. They suggested that $\mathrm{BC}$ emissions in East Asia, Southeast Asia, and eastern Europe are significantly underestimated in current bottom-up emission inventories. This issue is critically important, and possibly has an important implication for climate. However, an investigation of $\mathrm{BC}$ emissions for the SSA discrepancy above is beyond the scope of our work, and will be conducted in future studies.

Light absorption enhancement of aged BC could also be one of the reasons for the SSA overestimation in the model. Here we use the same optical parameters for all $\mathrm{BC}$ in the model. However, Bond et al. (2006) suggested that the absorption of aged $\mathrm{BC}$ is about 1.5 times greater than that of fresh BC. BC aging occurs as it is mixed internally with other aerosols. If we assume hydrophilic $\mathrm{BC}$ as aged $\mathrm{BC}$ in the model and its absorption enhancement by a factor of 1.5 relative to hydrophobic BC, the high bias of simulated SSA is additionally reduced by about $20 \%$ (not shown).

We further compare the model against AERONET AAE as shown in Fig. S1 in the Supplement. We find that the model overestimates the observed $\mathrm{AAE}$ after including $\mathrm{BrC}$, in part, because the model underestimates $\mathrm{BC}$ emissions as discussed above. However, the simulated AAE will be decreased if we increase $\mathrm{BC}$ emissions as suggested by the topdown estimate (Cohen and Wang, 2014). For example, for regions (North America, Central America, South America, Southeast Asia, and Australia) where the difference between our BC emission and the top-down estimate is within a factor of 2, we find that the model with $\mathrm{BrC}$ shows a better agreement with the observed AAE (Fig. S2) and with the observed SSA (Fig. S3).

Considering all these uncertainties, our evaluation above indicates that the model for case 2 results in the best estimates of simulated $\mathrm{BrC}$ concentrations, which will be used for examining $\mathrm{BrC}$ effects on climate and photochemistry below together with two other cases considered as the upper and lower limits of our estimates.

\section{Global budgets}

\subsection{Annual surface concentration}

Figure 6 shows our best estimates of annual mean concentrations of $\mathrm{BrC}$ and each source contribution in surface air for 2007. Values are high in regions where biomass burning (Southeast Asia and South America) and biofuel (East Asia and northeast India) sources are dominant. These primary sources account for $77 \%$ of $\mathrm{BrC}$ concentrations in surface air. On the other hand, secondary sources are relatively minor in the surface, but their contribution increases in the free troposphere, as discussed in Sect. 5.2.

Figure 7 shows $\mathrm{BrC}$ to $\mathrm{BC}$ and $\mathrm{OC}$ ratios in surface air in the model. The $\mathrm{BrC}$ to $\mathrm{BC}$ ratio is highest over the eastern North Pacific and the North Atlantic. This high ratio over the ocean reflects a secondary chemical production, which contributes to $\mathrm{BrC}$ but not to $\mathrm{BC}$. Over the continents, the ratio is generally higher in heavy biomass burning regions 
Table 3. Global tropospheric budgets of $\mathrm{BrC}$ compared to those of $\mathrm{OC}$ and $\mathrm{BC}$. Uncertainties are indicated in the parentheses.

\begin{tabular}{|c|c|c|c|c|c|c|c|}
\hline \multirow{2}{*}{$\begin{array}{l}\text { Unit: (GgC) } \\
\text { Sources }\end{array}$} & \multicolumn{3}{|c|}{$\mathrm{BrC}$} & \multirow{2}{*}{$\begin{array}{r}\text { OC } \\
46929\end{array}$} & \multirow{2}{*}{$\begin{array}{r}\text { BC } \\
6847\end{array}$} & \multirow{2}{*}{$\frac{\mathrm{BrC} / \mathrm{OC}}{0.27( \pm 0.06)}$} & \multirow{2}{*}{$\frac{\mathrm{BrC} / \mathrm{BC}}{1.83( \pm 0.43)}$} \\
\hline & Biomass burning & 3857 & $( \pm 1689)$ & & & & \\
\hline & Biofuel & 2965 & $( \pm 1281)$ & & & & \\
\hline & Anthropogenic SOC & 5690 & & & & & \\
\hline & Total & 12512 & $( \pm 2970)$ & & & & \\
\hline \multirow[t]{4}{*}{ Wet deposition } & Biomass burning & 3169 & $( \pm 1389)$ & 38681 & 5458 & $0.28( \pm 0.07)$ & $1.97( \pm 0.45)$ \\
\hline & Biofuel & 2358 & $( \pm 1018)$ & & & & \\
\hline & Anthropogenic SOC & 5244 & & & & & \\
\hline & Total & 10771 & $( \pm 2407)$ & & & & \\
\hline \multirow[t]{4}{*}{ Dry deposition } & Biomass burning & 688 & $( \pm 301)$ & 8272 & 1397 & $0.21( \pm 0.07)$ & $1.25( \pm 0.41)$ \\
\hline & Biofuel & 607 & $( \pm 263)$ & & & & \\
\hline & Anthropogenic SOC & 445 & & & & & \\
\hline & Total & 1740 & $( \pm 564)$ & & & & \\
\hline \multirow[t]{4}{*}{ Burden } & Biomass burning & 59 & $( \pm 26)$ & 1021 & 107 & $0.19( \pm 0.05)$ & $1.84( \pm 0.41)$ \\
\hline & Biofuel & 40 & $( \pm 18)$ & & & & \\
\hline & Anthropogenic SOC & 98 & & & & & \\
\hline & Total & 197 & $( \pm 44)$ & & & & \\
\hline \multirow[t]{4}{*}{ Lifetime (days) } & Biomass burning & 5.6 & $( \pm 0.0)$ & 7.9 & 5.7 & & \\
\hline & Biofuel & 5.0 & $( \pm 0.0)$ & & & & \\
\hline & Anthropogenic SOC & 6.3 & & & & & \\
\hline & Total & 5.8 & $( \pm 0.1)$ & & & & \\
\hline
\end{tabular}
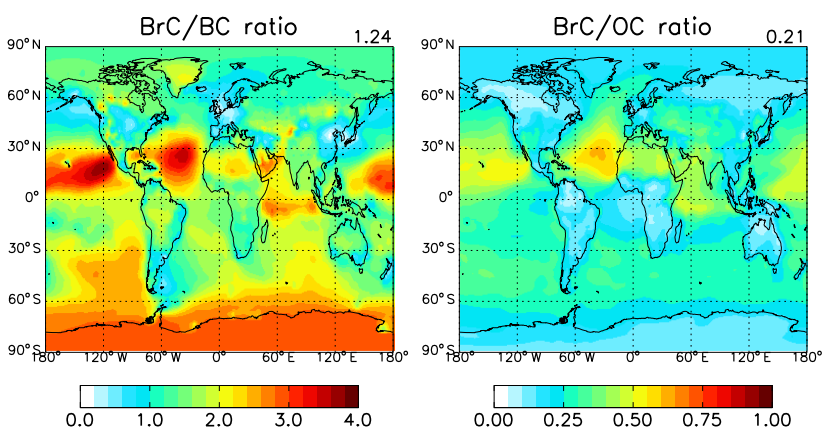

Figure 7. Annual mean ratios of $\mathrm{BrC}$ to $\mathrm{BC}$ (left) and $\mathrm{OC}$ (right) in surface air. Global mean values are presented in the upper right corner of each panel.

(South America and Africa) than in industrialised regions (East Asia, Europe, and the eastern United States) because more $\mathrm{BrC}$ than $\mathrm{BC}$ is emitted from biomass burning.

Similarly, the $\mathrm{BrC}$ to $\mathrm{OC}$ ratio is also high over the oceans because of secondary $\mathrm{BrC}$, the concentrations of which increase with atmospheric aging. Over the continents, the ratio is smaller reflecting relatively fresh emissions of $\mathrm{OC}$ from anthropogenic sources that do not directly contribute to $\mathrm{BrC}$. We find that the $\mathrm{BrC}$ to $\mathrm{OC}$ ratio is relatively high in regions with large biofuel use (northern India and central Asia). Although China is one of the largest emission source regions for $\mathrm{BrC}$ (Fig. 6), both $\mathrm{BrC}$ to $\mathrm{BC}$ and $\mathrm{BrC}$ to $\mathrm{OC}$ ratios are relatively low because of high concentrations of $\mathrm{BC}$ and $\mathrm{OC}$.
Our global mean $\mathrm{BrC}$ to $\mathrm{BC}$ and $\mathrm{BrC}$ to $\mathrm{OC}$ ratios at the surface are 1.24 and 0.21 , respectively, and are lower than the ratio (3.4 of $\mathrm{BrC}$ to $\mathrm{BC}$ ratio and 0.43 of $\mathrm{BrC}$ to $\mathrm{OC}$ ratio in terms of burden) of Feng et al. (2013), but higher than the ratio (1.0 of BrC to BC ratio) used in Park et al. (2010).

\subsection{Tropospheric budget of $\mathrm{BrC}$}

Table 3 summarises our best estimates of the global tropospheric budgets of $\mathrm{BrC}$, along with $\mathrm{BC}$ and $\mathrm{OC}$. The global $\mathrm{BrC}$ source is $12.5 \pm 3.0 \mathrm{TgC}^{-1} r^{-1}$, which accounts for $27 \%$ of $\mathrm{OC}$ sources. Although the biofuel emission

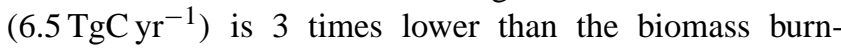
ing emission $\left(22.7{\mathrm{TgC} \mathrm{yr}^{-1}}^{-1}\right.$ ) for $\mathrm{OC}$, the biofuel emission $\left(3.0 \pm 1.3 \mathrm{TgC}^{-1} \mathrm{r}^{-1}\right)$ becomes significant for $\mathrm{BrC}$, contributing about $43 \%$ of primary sources. The secondary source of $\mathrm{BrC}$ is $5.7 \mathrm{TgC}^{-1}$, and is comparable to the primary sources $\left(6.8 \pm 3.0 \mathrm{TgC}^{-1}\right)$.

Wet deposition is the main removal process for $\mathrm{BrC}$, and accounts for $86 \%$ of total removal processes. The remaining loss is due to dry deposition. The contribution of wet deposition to total deposition of $\mathrm{BrC}$ is similar to that of $\mathrm{OC}(82 \%)$, because we treat $\mathrm{BrC}$ scavenging similarly to that of $\mathrm{OC}$. Because secondary $\mathrm{BrC}$ is produced all over the troposphere (not only at the surface) and is hydrophilic, most secondary $\mathrm{BrC}$ is removed through wet deposition processes (92\%).

The global burden of $\mathrm{BrC}$ shows the highest contribution from secondary $\mathrm{BrC}(50 \%)$ compared to primary contributions from biomass burning $(30 \%)$ and biofuel $(20 \%)$. This 

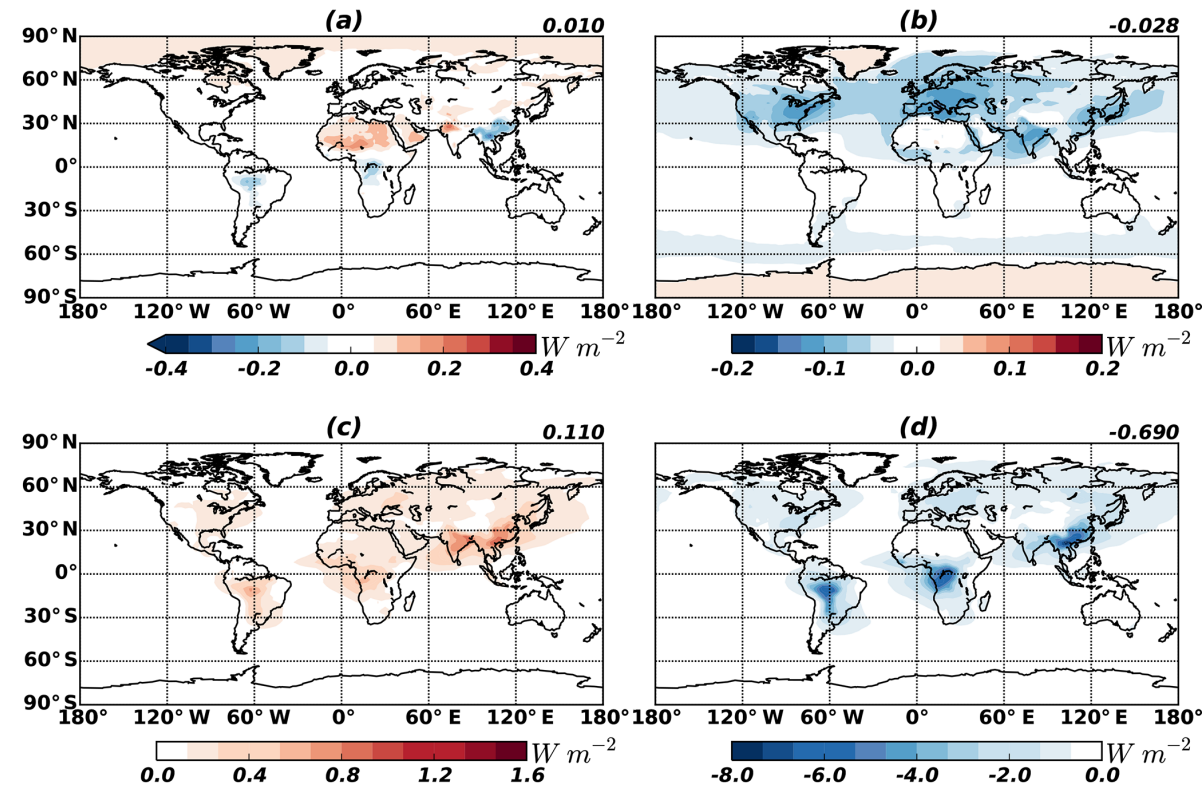

Figure 8. $\mathrm{DRE}$ of $\mathrm{BrC}$ at the top of the atmosphere. Upper panels are for radiative effect of $\mathrm{BrC}$ from primary sources (a) and from secondary sources (b). The DRE increase of OC owing to the absorption of $\mathrm{BrC}$ is shown in (c) (i.e. the DRE of OC with absorbing BrC minus the DRE of OC including BrC as scattering OC, which is typically assumed in previous studies). Radiative effect of total $\mathrm{OC}$ (BrC is assumed to be scattering OC) is represented in (d). The $70^{\circ} \mathrm{S}-70^{\circ} \mathrm{N}$ averages are shown in the upper right corner of each panel.

result is opposite to the source contributions in surface air shown in Fig. 6. The contribution of secondary $\mathrm{BrC}$ to the atmospheric burden is twice as high as the contribution of secondary $\mathrm{BrC}$ to the surface concentration (23\%), reflecting a relatively large production of $\mathrm{BrC}$ in the free troposphere as well as limited export of primary $\mathrm{BrC}$ from the surface to the free troposphere.

Our BrC lifetime is 5.8 days, which is lower than that of OC (7.9 days) because of different contributions of the secondary sources for $\mathrm{BrC}$ and $\mathrm{OC}$. The latter species includes a larger fraction of secondary species (52\%), the lifetime of which is usually longer than that of POC especially for not aged biogenic SOC (Jo et al., 2013). No significant difference between the lifetimes of $\mathrm{BrC}$ and $\mathrm{BC}$ exists because $\mathrm{BrC}$, which is more hydrophilic than $\mathrm{BC}$, is more prone to wet scavenging than $\mathrm{BC}$.

\section{Direct radiative effect of $\mathrm{BrC}$}

We use imaginary refractive indices of $\mathrm{BrC}$ as a function of wavelength for radiative transfer calculations to account for the wavelength dependency of the $\mathrm{BrC}$ absorption. Imaginary refractive indices in the literature have a wide range of values, even from the same sources, such as wood burning (Chakrabarty et al., 2010; Kirchstetter et al., 2004; McMeeking, 2008). In order to maintain the consistency with $\mathrm{BrC}$ emission estimates from primary sources, we use the imaginary refractive indices reported by McMeeking (2008), which are $0.18,0.14$, and 0.10 at 370,405 , and $532 \mathrm{~nm}$, respectively. The values are interpolated with the AAE at every $50 \mathrm{~nm}$ wavelength interval for the radiative transfer calculations. For secondary $\mathrm{BrC}$, values from Nakayama et al. (2010) are used with 0.047 and 0.007 at 355 and $532 \mathrm{~nm}$, respectively, based on the measurements for SOC from toluene.

We calculate AOD, SSA, and asymmetry parameter using FlexAOD, which is described in Sect. 4.2. Note that we calculate DRE rather than DRF. DRE is the instantaneous radiative impact of all atmospheric particles on the Earth's energy balance, and DRF is the change in DRE from preindustrial to present day (Heald et al., 2014). We use the rapid radiative transfer model for GCMs (general circulation models) (RRTMGs) (Iacono et al., 2008) for DRE calculations. Wavelengths used for the calculation are 300, 304, 393, 533, $702,1010,1270,1462,1784,2046,2325,2788,3462$, and $8021 \mathrm{~nm}$. MERRA reanalysis data are used for albedo and other meteorological variables.

Figure $8 \mathrm{a}$ and $\mathrm{b}$ show the clear-sky DRE values of primary and secondary $\mathrm{BrC}$ concentrations. Because the imaginary refractive indices of $\mathrm{BrC}$ are between those of strongly absorbing $\mathrm{BC}$ and scattering $\mathrm{OC}$, the global mean DRE of $\mathrm{BrC}$ is close to zero, as shown in a and $b$.

Although the DRE of $\mathrm{BrC}$ at the top of the atmosphere is nearly zero, the increased DRE of OC after considering $\mathrm{BrC}$ absorption (usually considered as scattering $\mathrm{OC}$ ) is $0.11 \mathrm{~W} \mathrm{~m}^{-2}$, as shown in Fig. 8c. The DRE of OC without $\mathrm{BrC}$ absorption is $-0.69 \mathrm{~W} \mathrm{~m}^{-2}$ (Fig. $8 \mathrm{~d}$ ), and this value is 
Table 4. Extinction efficiencies and SSAs of selected aerosols at $0.4 \mu \mathrm{m}$ used for calculating photolysis rates in GEOS-Chem. SNA indicates inorganic salt comprised of sulfate, nitrate and ammonium aerosols.

\begin{tabular}{lrrrrrr}
\hline $0.4 \mu \mathrm{m}$ & $\mathrm{RH}$ & $\mathrm{BrC}$ (primary) & $\mathrm{BrC}$ (secondary) & $\mathrm{OC}$ & $\mathrm{BC}$ & $\mathrm{SNA}$ \\
\hline Extinction efficiency & $0 \%$ & 1.4644 & 1.2922 & 1.3933 & 0.6229 & 1.2147 \\
& $50 \%$ & 1.6995 & 1.5645 & 1.4967 & 0.6229 & 1.6566 \\
& $70 \%$ & 1.7873 & 1.6781 & 1.5815 & 0.6229 & 1.8440 \\
& $90 \%$ & 1.8386 & 1.7474 & 1.8485 & 0.4607 & 2.2568 \\
& $99 \%$ & 2.2696 & 2.4390 & 2.5870 & 0.4181 & 2.9655 \\
\hline Single scattering albedo & $0 \%$ & 0.5621 & 0.8683 & 0.9735 & 0.1935 & 1.0000 \\
& $50 \%$ & 0.5474 & 0.8584 & 0.9841 & 0.1935 & 1.0000 \\
& $70 \%$ & 0.5422 & 0.8540 & 0.9873 & 0.1935 & 1.0000 \\
& $90 \%$ & 0.5342 & 0.8480 & 0.9927 & 0.3004 & 1.0000 \\
& $99 \%$ & 0.5412 & 0.8372 & 0.9977 & 0.5233 & 1.0000 \\
\hline
\end{tabular}

increased to $-0.58 \mathrm{~W} \mathrm{~m}^{-2}$ after considering $\mathrm{BrC}$ absorption. Consequently, the cooling effect of OC is reduced by $16 \%$.

Despite the negligible effect of $\mathrm{BrC}$ on DRE or DRF, its significance manifests for OC DRF estimates, which have been conducted based on the assumption of scattering OC. For example, AeroCom phase II simulations calculated $-0.03 \mathrm{~W} \mathrm{~m}^{-2}$ as the global mean DRF of POC from fossil fuel and biofuel, and $-0.06 \mathrm{~W} \mathrm{~m}^{-2}$ for that of SOC (Myhre et al., 2013). Because the biofuel emission is about twice as large as the fossil fuel emission (Bond et al., 2007), and onehalf of $\mathrm{OC}$ from biofuel is $\mathrm{BrC}$, one-third of the $\mathrm{POC}$ from fossil fuel and biofuel is BrC. Therefore, one-third of DRF $\left(-0.01 \mathrm{~W} \mathrm{~m}^{-2}\right)$ of $\mathrm{POC}$ in AeroCom is related to $\mathrm{BrC}$, whose DRF is close to zero. For SOC, because the pre-industrial biogenic SOC concentration is similar to present-day conditions, almost all DRF of SOC is from anthropogenic SOC. Based on previous SOC studies (Henze et al., 2008; Jo et al., 2013; Murphy and Pandis, 2010), approximately one-third of anthropogenic SOC is highly aged, and can thus be assumed to be $\mathrm{BrC}$ in this simple estimation. As a result, one-third of DRF $\left(-0.02 \mathrm{~W} \mathrm{~m}^{-2}\right)$ of SOC in AeroCom is related to $\mathrm{BrC}$. The total DRF of BrC that was assumed to be scattering $\mathrm{OC}$ in the AeroCom study is $-0.03 \mathrm{~W} \mathrm{~m}^{-2}$. Because $\mathrm{DRF}$ of $\mathrm{BrC}$ is almost negligible, the negative DRF of OC $\left(-0.09 \mathrm{~W} \mathrm{~m}^{-2}\right)$ in AeroCom could likely be overestimated by $50 \%$. We think, however, the warming effect of $\mathrm{BrC}$ on the negative DRF or DRE of OC would be a low-end value because our best model likely underestimates $\mathrm{BrC}$ concentrations especially from the secondary source.

\section{Effect on ozone photochemistry}

BrC absorption, particularly at UV wavelengths, has an important implication for ozone photochemistry. Here we examine the effect of $\mathrm{BrC}$ absorption on photochemistry by updating photolysis rate calculations in GEOS-Chem following Martin et al. (2003). Table 4 shows the calculated extinction efficiency and SSA of important aerosols at $0.4 \mu \mathrm{m}$, which affect UV extinction, and thus photolysis rate calculations, in the model. Values of OC, BC, and inorganic aerosols are from GEOS-Chem, in which we update aerosol optical properties by adding those of $\mathrm{BrC}$. We include optical properties of primary and secondary $\mathrm{BrC}$ separately because they differ substantially. For example, SSA values of primary $\mathrm{BrC}$ are smaller than those of secondary $\mathrm{BrC}$, and thus have a greater impact on UV radiation. Compared with other aerosols, SSA values of $\mathrm{BrC}$ are generally lower than those of $\mathrm{OC}$ and inorganic aerosols, but higher than those of BC.

Martin et al. (2003) showed that the effects of aerosols on photolysis rates increased $\mathrm{CO}$ by $5-15 \mathrm{ppbv}$ in the remote Northern Hemisphere (annual mean concentrations less than $140 \mathrm{ppbv}$ ). This increase resulted in an improved model agreement with observations, but there was a still gap between the model and the observations. In our simulation with $\mathrm{BrC}, \mathrm{CO}$ concentration is further increased by $0.2-1.9 \mathrm{ppbv}$ in remote Northern Hemisphere regions (annual mean concentrations less than $140 \mathrm{ppbv}$ in the model). On the other hand, $\mathrm{OH}$ concentrations are decreased by $0-10 \%$ in the boundary layer over the Northern Hemisphere (maximum decreases occur in regions with high $\mathrm{BrC}$ concentrations, shown in Fig. 6). The change of $\mathrm{OH}$ owing to $\mathrm{BrC}$ is about one-third of the $\mathrm{OH}$ change according to the overall aerosol effects from Martin et al. (2003). Therefore, the inclusion of $\mathrm{BrC}$ significantly affects tropospheric chemistry, especially for regions with heavy biomass burning and biofuel emissions.

Finally, we quantify the effects of $\mathrm{BrC}$ on global $\mathrm{NO}_{2}$ photolysis rates and ozone concentrations at the surface. Figure 9 shows changes in annual $\mathrm{NO}_{2}$ photolysis rates and $\mathrm{O}_{3}$ concentrations in surface air owing to $\mathrm{BrC}$ absorption. Although $\mathrm{BrC}$ absorption is included, there are no significant changes (less than $1 \%$ ) of the global mean $\mathrm{NO}_{2}$ photolysis rate and $\mathrm{O}_{3}$ concentration in surface air. However, the effect of $\mathrm{BrC}$ appears to be important for regions with high $\mathrm{BrC}$ concentrations. We find a maximum decrease of the annual mean $\mathrm{NO}_{2}$ photolysis rate by $8 \%$ in surface air over Asia where 

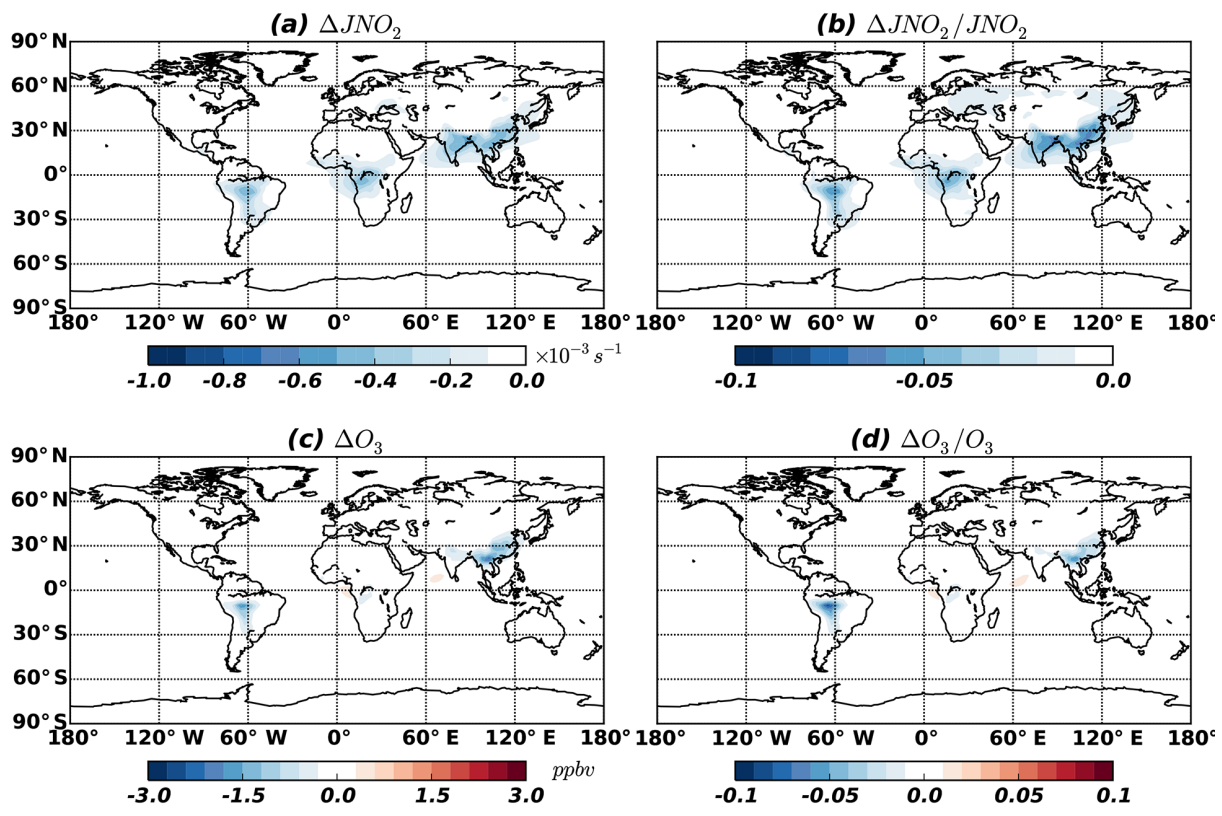

Figure 9. Changes in annual $\mathrm{NO}_{2}$ photolysis rate $(\mathbf{a}, \mathbf{b})$ and $\mathrm{O}_{3}$ concentration $(\mathbf{c}, \mathbf{d})$ at the surface due to $\mathrm{BrC}$ absorption.

the resulting reduction of $\mathrm{O}_{3}$ concentration is up to $-2 \mathrm{ppbv}$ ( $6 \%$ of annual mean surface $\mathrm{O}_{3}$ concentration). We also find that the $\mathrm{BrC}$ effect has a strong seasonal variation such that it is maximised in the spring when surface $\mathrm{O}_{3}$ concentration is decreased up to $-13 \%$ in Asia because of high $\mathrm{BrC}$ concentration $\left(55 \mu \mathrm{gC} \mathrm{m}^{-3}\right)$. This maximum $\mathrm{O}_{3}$ decrease by $\mathrm{BrC}$ $(-13 \%)$ is similar to the $\mathrm{O}_{3}$ decrease $(15 \%)$ by fire aerosols in Jiang et al. (2012).

\section{Conclusion}

OC has been considered to be a scattering aerosol, but emerging evidence has shown that some OC can efficiently absorb solar radiation. This absorbing $\mathrm{OC}$ is called $\mathrm{BrC}$. With increasing recognition of its importance, especially for solar absorption at UV and short visible wavelengths, quantification of its spatial and temporal distribution is much needed for the study of climate and air quality issues. Here we conducted an explicit global $\mathrm{BrC}$ simulation for the full year of 2007 using a global 3-D chemical transport model (GEOSChem), and examined its implication for climate and $\mathrm{O}_{3}$ photochemistry.

We first estimated primary $\mathrm{BrC}$ emissions from biomass burning and biofuel use based on the relationship between $\mathrm{AAE}$ and MCE. Our estimates of primary $\mathrm{BrC}$ emissions are $3.9 \pm 1.7$ and $3.0 \pm 1.3 \mathrm{TgC} \mathrm{yr}^{-1}$ from biomass burning and biofuel use, respectively. The secondary $\mathrm{BrC}$ source is estimated to be $5.7 \mathrm{TgC}^{-1}$ from the aromatic oxidation.
With explicit $\mathrm{BrC}$ emissions, a coupled oxidant-aerosol simulation was conducted for 2007 to obtain the spatial and temporal distributions of $\mathrm{BrC}$ concentrations. We first evaluated the model by comparing the simulated versus observed $\mathrm{BrC}$ absorption in the United States and found that the model successfully reproduced the observed seasonal variation of light absorption by WSOC in the southeastern United States, whereas the model significantly underestimated secondary $\mathrm{BrC}$ over the Los Angeles basin.

Our budget analysis showed that $\mathrm{BrC}$ from primary sources are dominant $(77 \%)$ in surface air, but $\mathrm{BrC}$ from secondary sources becomes important with increasing altitudes. For example, $\mathrm{BrC}$ from secondary sources accounts for the $50 \%$ of the tropospheric $\mathrm{BrC}$ burden, which is higher than its $23 \%$ contribution to surface $\mathrm{BrC}$ concentrations. Our global mean value of the $\mathrm{BrC}$ to $\mathrm{BC}$ ratio is 1.83 for the whole atmosphere, and 1.24 for the surface, which significantly differs from the values used in previous studies.

Using our best results, we estimated the DRE of $\mathrm{BrC}$ to be close to zero at the top of the atmosphere because the imaginary refractive indices of $\mathrm{BrC}$ are in the midpoint between those of $\mathrm{BC}$ and OC. Despite a negligible contribution to DRE, the inclusion of $\mathrm{BrC}$ absorption in the model offsets the negative radiative effect of OC by $0.11 \mathrm{~W} \mathrm{~m}^{-2}(16 \%)$. 
Finally, we included $\mathrm{BrC}$ absorption in photolysis rate calculations in the model. We found that the $\mathrm{NO}_{2}$ photolysis rate is decreased up to $8 \%$, especially for Asia, where $\mathrm{BrC}$ concentration is high. Resulting annual surface $\mathrm{O}_{3}$ concentrations are decreased up to -2 ppbv $(6 \%)$. This effect is more important in the spring, when a typical $\mathrm{O}_{3}$ maximum occurs in Asia, where the effect of $\mathrm{BrC}$ decreases the surface $\mathrm{O}_{3}$ concentration by up to $-13 \%$.

Many chemical transport models and air quality models have included the effect of aerosols on photolysis rate cal- culations, but have not considered the $\mathrm{BrC}$ effect. Based on our analysis, $\mathrm{BrC}$ absorption could have a significant direct impact on regional air quality by being involved in $\mathrm{O}_{3}$ photochemical formation. Its significance, however, can be expanded to the globe by its effect on the atmospheric oxidation capacity, which has an indirect but important implication for global air quality and climate. 


\section{Appendix A}

\section{A1 Relationship between $\mathrm{BrC} / \mathrm{BC}$ absorption ratio and $\mathrm{AAE}$}

In this section we describe a procedure for obtaining the relationship between the $\mathrm{BrC} / \mathrm{BC}$ absorption ratio and $\mathrm{AAE}$. Assuming no internal mixing and dust influence, total absorption at a certain wavelength $(\lambda)$ can be expressed as

$\alpha_{\lambda, \mathrm{CA}}=\alpha_{\lambda, \mathrm{BrC}}+\alpha_{\lambda, \mathrm{BC}}$.

Rewriting Eq. (A1) using AAE,

$$
\begin{aligned}
\alpha_{\lambda_{0}, \mathrm{CA}}\left(\frac{\lambda}{\lambda_{0}}\right)^{-\AA_{\mathrm{CA}}} & =\alpha_{\lambda_{0}, \mathrm{BrC}}\left(\frac{\lambda}{\lambda_{0}}\right)^{-\AA_{\mathrm{BrC}}} \\
& +\alpha_{\lambda_{0}, \mathrm{BC}}\left(\frac{\lambda}{\lambda_{0}}\right)^{-\AA_{\mathrm{BC}}} .
\end{aligned}
$$

Dividing each side of Eq. (A2) by $\alpha_{\lambda_{0}, \mathrm{BC}}$ :

$$
(1+F)\left(\frac{\lambda}{\lambda_{0}}\right)^{-\AA_{\mathrm{CA}}}=F\left(\frac{\lambda}{\lambda_{0}}\right)^{-\AA_{\mathrm{BrC}}}+\left(\frac{\lambda}{\lambda_{0}}\right)^{-\AA_{\mathrm{BC}}},
$$

where $F$ is the $\mathrm{BrC} / \mathrm{BC}$ absorption ratio at $\lambda_{0}$.

We can solve Eq. (A3) analytically, and the procedure is described in Appendix A2. We do not use the analytical relationship because it uses only three wavelengths for the calculations. The Ångström relationship is based on empirical fitting. AAE varies in different wavelength regions, even if we use the same samples. For example, Chung et al. (2012) showed that CA AAE is about 1.2 when the first four wavelengths $(370,470,520,590 \mathrm{~nm})$ are used, while the CA AAE is 1.35 with the last four wavelengths $(590,660$, $880,950 \mathrm{~nm})$. This discrepancy is much increased in the case of BrC AAE. Liu et al. (2014) showed that BrC AAE varies by approximately $20 \%$, depending on wavelength pairs. Furthermore, if we calculate AAE of $\mathrm{BrC}$ using the MAE of Kirchstetter et al. (2004), AAE of $\mathrm{BrC}$ in all wavelengths (from 350 to $650 \mathrm{~nm}, 7$ values) is fitted to 5.9 with a $R^{2}$ of 0.96. However, the AAE of $\mathrm{BrC}$ using just two wavelengths is 4.1 for the $350-440 \mathrm{~nm}$ and 8.0 for the $550-600 \mathrm{~nm}$.
Therefore, we calculate the relationship between MCE and $F$ by regression using multiple wavelengths: $[300,350,400$, $450,500,550,600,650,700,750,800,850,900 \mathrm{~nm}]$. If we rewrite Eq. (A3) for the regression form,

$$
\begin{aligned}
& \AA_{\mathrm{CA}} \log (\lambda)+C= \\
& -\log \left[F\left(\frac{\lambda}{\lambda_{0}}\right)^{-\AA_{\mathrm{BrC}}}+\left(\frac{\lambda}{\lambda_{0}}\right)^{-\AA_{\mathrm{BC}}}\right],
\end{aligned}
$$

where the residual term $C$ is

$$
C=-\AA_{\mathrm{CA}} \log \left(\lambda_{0}\right)-\log (1+F) .
$$

The left side of Eq. (A4) has the shape of $A x+B$. Therefore, by linear regression analysis, we can obtain $\AA_{\mathrm{CA}}$ (the slope of the regression) as varying $\mathrm{F}$ on the right side. For example, Fig. S4 shows the linear regression case for $F=4.0$. In this case, $R^{2}$ is 0.99 and Ångström exponent of CA is 4.44. $Y$ intercept of the numerical fitting is -29.81 , which is consistent with $Y$ intercept (-29.64) from Eq. (A5). The difference between two $Y$ intercept values are always within $1 \%$, which shows the numerical fitting with Eq. (A4) satisfies both the slope $(A)$ and the intercept $(B)$ at the same time within $1 \%$ error. We choose an $\AA_{\mathrm{BrC}}$ values of $\{5.0,5.48,6.19\}$ and an $\AA_{B C}$ values of $\{0.86,1.00,1.15\}$, following Kirchstetter and Thatcher (2012), who estimated mean $\AA_{\mathrm{BrC}}$ using several wood samples ( 87 samples) over the 360 to $700 \mathrm{~nm}$ spectrum range. We assign a $\lambda_{0}$ value of $550 \mathrm{~nm}$. The coefficient of determination $\left(R^{2}\right)$ is greater than 0.98 in all the regression analyses. The calculated relationship between MCE and F is plotted in Fig. 1. As expected, emissions of $\mathrm{BrC}$ are increased when MCE is decreased. 


\section{A2 Analytical derivation of Eq. (A3)}

Here we describe the procedure to obtain the analytical relationship between MCE and $F$. First, substituting $\lambda_{1}$ and $\lambda_{2}$ in Eq. (A3),

$$
\begin{aligned}
& (1+F)\left(\frac{\lambda_{1}}{\lambda_{0}}\right)^{-\AA_{\mathrm{CA}}}=F\left(\frac{\lambda_{1}}{\lambda_{0}}\right)^{-\AA_{\mathrm{BrC}}}+\left(\frac{\lambda_{1}}{\lambda_{0}}\right)^{-\AA_{\mathrm{BC}}}, \\
& (1+F)\left(\frac{\lambda_{2}}{\lambda_{0}}\right)^{-\AA_{\mathrm{CA}}}=F\left(\frac{\lambda_{2}}{\lambda_{0}}\right)^{-\AA_{\mathrm{BrC}}}+\left(\frac{\lambda_{2}}{\lambda_{0}}\right)^{-\AA_{\mathrm{BC}}} .
\end{aligned}
$$

Assuming AAE between $\lambda_{0}$ and $\lambda_{1}$ is equal to AAE between $\lambda_{0}$ and $\lambda_{2}$, divide Eq. (A6) by Eq. (A7), and rearrange terms:

$$
\begin{aligned}
\left(\frac{\lambda_{1}}{\lambda_{2}}\right)^{-\AA_{\mathrm{CA}}} & =\frac{F\left(\frac{\lambda_{1}}{\lambda_{0}}\right)^{-\AA_{\mathrm{BrC}}}+\left(\frac{\lambda_{1}}{\lambda_{0}}\right)^{-\AA_{\mathrm{BC}}}}{F\left(\frac{\lambda_{2}}{\lambda_{0}}\right)^{-\AA_{\mathrm{BrC}}}} \\
& +\left(\frac{\lambda_{2}}{\lambda_{0}}\right)^{-\AA_{\mathrm{BC}}} .
\end{aligned}
$$

Taking the logarithm of both sides:

$$
\begin{aligned}
& \AA_{\mathrm{CA}}= \\
& -\log \left(\frac{F\left(\frac{\lambda_{1}}{\lambda_{0}}\right)^{-\AA_{\mathrm{BrC}}}+\left(\frac{\lambda_{1}}{\lambda_{0}}\right)^{-\AA_{\mathrm{BC}}}}{F\left(\frac{\lambda_{2}}{\lambda_{0}}\right)^{-\AA_{\mathrm{BrC}}}+\left(\frac{\lambda_{2}}{\lambda_{0}}\right)^{-\AA_{\mathrm{BC}}}}\right) / \log \left(\frac{\lambda_{1}}{\lambda_{2}}\right) .
\end{aligned}
$$

Substituting Eq. (2) into Eq. (A9) gives

$$
\begin{aligned}
& \mathrm{MCE}= \\
& {\left[18.2+\log \left(\frac{F\left(\frac{\lambda_{1}}{\lambda_{0}}\right)^{-\AA_{\mathrm{BrC}}}+\left(\frac{\lambda_{1}}{\lambda_{0}}\right)^{-\AA_{\mathrm{BC}}}}{F\left(\frac{\lambda_{2}}{\lambda_{0}}\right)^{-\AA_{\mathrm{BrC}}}+\left(\frac{\lambda_{2}}{\lambda_{0}}\right)^{-\AA_{\mathrm{BC}}}}\right) /\right.} \\
& \left.\log \left(\frac{\lambda_{1}}{\lambda_{2}}\right)\right] / 17.34 .
\end{aligned}
$$

After assigning $\AA_{\mathrm{BrC}}, \AA_{\mathrm{BC}}$, and the corresponding three wavelengths $\left(\lambda_{0}, \lambda_{1}\right.$ and $\left.\lambda_{2}\right)$ in Eq. (A10), we obtain the relationship between MCE and $F$ analytically. 


\section{The Supplement related to this article is available online at doi:10.5194/acp-16-3413-2016-supplement.}

Acknowledgements. We thank anonymous reviewers for their helpful comments on the manuscript. We thank the principal investigators and their staff for establishing and maintaining the AERONET sites used in this study. This study was supported by the Eco Innovation Program of KEITI (ARQ201204015) and by Korea Ministry of Environment as the "Climate Change Correspondence Program".

Edited by: K. Tsigaridis

\section{References}

Aiken, A. C., DeCarlo, P. F., Kroll, J. H., Worsnop, D. R., Huffman, J. A., Docherty, K. S., Ulbrich, I. M., Mohr, C., Kimmel, J. R., and Sueper, D.: O / C and OM / OC ratios of primary, secondary, and ambient organic aerosols with high-resolution timeof-flight aerosol mass spectrometry, Environ. Sci. Technol., 42, 4478-4485, 2008.

Akagi, S. K., Yokelson, R. J., Wiedinmyer, C., Alvarado, M. J., Reid, J. S., Karl, T., Crounse, J. D., and Wennberg, P. O.: Emission factors for open and domestic biomass burning for use in atmospheric models, Atmos. Chem. Phys., 11, 4039-4072, doi:10.5194/acp-11-4039-2011, 2011.

Alexander, D. T. L., Crozier, P. A., and Anderson, J. R.: Brown carbon spheres in East Asian outflow and their optical properties, Science, 321, 833-836, doi:10.1126/science.1155296, 2008.

Andreae, M. O. and Gelencsér, A.: Black carbon or brown carbon? The nature of light-absorbing carbonaceous aerosols, Atmos. Chem. Phys., 6, 3131-3148, doi:10.5194/acp-6-3131-2006, 2006.

Andreae, M. O. and Merlet, P.: Emission of trace gases and aerosols from biomass burning, Global Biogeochem. Cy., 15, 955-966, 2001.

Bahadur, R., Praveen, P. S., Xu, Y., and Ramanathan, V.: Solar absorption by elemental and brown carbon determined from spectral observations, P. Natl. Acad. Sci., 109, 17366-17371, 2012.

Bey, I., Jacob, D. J., Yantosca, R. M., and Logan, J. A.: Global modeling of tropospheric chemistry with assimilated meteorology Model description and evaluation, J. Geophys. Res., 106, 2307323095, 2001.

Bond, T. C. and Bergstrom, R. W.: Light absorption by carbonaceous particles: An investigative review, Aerosol Sci. Tech., 40, 27-67, 2006.

Bond, T. C., Streets, D. G., Yarber, K. F., Nelson, S. M., Woo, J. H., and Klimont, Z.: A technology-based global inventory of black and organic carbon emissions from combustion, J. Geophys. Res., 109, D14203, doi:10.1029/2003JD003697, 2004.

Bond, T. C., Habib, G., and Bergstrom, R. W.: Limitations in the enhancement of visible light absorption due to mixing state, J. Geophys. Res, 111, D20211, doi:10.1029/2006JD007315, 2006.

Bond, T. C., Bhardwaj, E., Dong, R., Jogani, R., Jung, S., Roden, C., Streets, D. G., and Trautmann, N. M.: Historical emissions of black and organic carbon aerosol from energy-related combustion, 1850-2000, Global Biogeochem. Cy., 21, GB2018, doi:10.1029/2006GB002840, 2007.

Bond, T. C., Doherty, S. J., Fahey, D. W., Forster, P. M., Berntsen, T., DeAngelo, B. J., Flanner, M. G., Ghan, S., Kärcher, B., Koch, D., Kinne, S., Kondo, Y., Quinn, P. K., Sarofim, M. C., Schultz, M. G., Schulz, M., Venkataraman, C., Zhang, H., Zhang, S., Bellouin, N., Guttikunda, S. K., Hopke, P. K., Jacobson, M. Z., Kaiser, J. W., Klimont, Z., Lohmann, U., Schwarz, J. P., Shindell, D., Storelvmo, T., Warren, S. G., and Zender, C. S.: Bounding the role of black carbon in the climate system: A scientific assessment, J. Geophys. Res., 118, 5380-5552, doi:10.1002/jgrd.50171, 2013.

Bones, D. L., Henricksen, D. K., Mang, S. A., Gonsior, M., Bateman, A. P., Nguyen, T. B., Cooper, W. J., and Nizkorodov, S. A.: Appearance of strong absorbers and fluorophores in limonene$\mathrm{O}_{3}$ secondary organic aerosol due to $\mathrm{NH}_{4}^{+}$-mediated chemical aging over long time scales, J. Geophys. Res., 115, D05203, doi:10.1029/2009JD012864, 2010.

Chakrabarty, R. K., Moosmüller, H., Chen, L.-W. A., Lewis, K., Arnott, W. P., Mazzoleni, C., Dubey, M. K., Wold, C. E., Hao, W. M., and Kreidenweis, S. M.: Brown carbon in tar balls from smoldering biomass combustion, Atmos. Chem. Phys., 10, 63636370, doi:10.5194/acp-10-6363-2010, 2010.

Chakrabarty, R. K., Pervez, S., Chow, J. C., Watson, J. G., Dewangan, S., Robles, J., and Tian, G.: Funeral pyres in South Asia: Brown carbon aerosol emissions and climate impacts, Environ. Sci. Tech. Lett., 1, 44-48, 2014.

Cheng, Y., He, K.-B., Zheng, M., Duan, F.-K., Du, Z.-Y., Ma, Y.L., Tan, J.-H., Yang, F.-M., Liu, J.-M., Zhang, X.-L., Weber, R. J., Bergin, M. H., and Russell, A. G.: Mass absorption efficiency of elemental carbon and water-soluble organic carbon in Beijing, China, Atmos. Chem. Phys., 11, 11497-11510, doi:10.5194/acp11-11497-2011, 2011.

Chin, M., Diehl, T., Dubovik, O., Eck, T. F., Holben, B. N., Sinyuk, A., and Streets, D. G.: Light absorption by pollution, dust, and biomass burning aerosols: a global model study and evaluation with AERONET measurements, Ann. Geophys., 27, 3439-3464, doi:10.5194/angeo-27-3439-2009, 2009.

Chung, C. E., Kim, S.-W., Lee, M., Yoon, S.-C., and Lee, S.: Carbonaceous aerosol AAE inferred from in-situ aerosol measurements at the Gosan $\mathrm{ABC}$ super site, and the implications for brown carbon aerosol, Atmos. Chem. Phys., 12, 6173-6184, doi:10.5194/acp-12-6173-2012, 2012.

Chung, S. and Seinfeld, J.: Global distribution and climate forcing of carbonaceous aerosols, J. Geophys. Res., 107, 4407, doi:10.1029/2001JD001397, 2002.

Clarke, A., McNaughton, C., Kapustin, V., Shinozuka, Y., Howell, S., Dibb, J., Zhou, J., Anderson, B., Brekhovskikh, V., and Turner, H.: Biomass burning and pollution aerosol over North America: Organic components and their influence on spectral optical properties and humidification response, J. Geophys. Res., 112, D12S18, doi:10.1029/2006JD007777, 2007.

Cohen, J. B. and Wang, C.: Estimating global black carbon emissions using a top-down Kalman Filter approach, J. Geophys. Res.-Atmos., 119, 307-323, 2014.

Cooke, W., Liousse, C., Cachier, H., and Feichter, J.: Construction of a $1 \times 1$ fossil fuel emission data set for carbonaceous aerosol and implementation and radiative impact in the ECHAM4 model, J. Geophys. Res., 104, 22137-22162, 1999. 
Curci, G., Hogrefe, C., Bianconi, R., Im, U., Balzarini, A., Baró, R., Brunner, D., Forkel, R., Giordano, L., Hirtl, M., Honzak, L., Jiménez-Guerrero, P., Knote, C., Langer, M., Makar, P. A., Pirovano, G., Pérez, J. L., San José, R., Syrakov, D., Tuccella, P., Werhahn, J., Wolke, R., Žabkar, R., Zhang, J., and Galmarini, S.: Uncertainties of simulated aerosol optical properties induced by assumptions on aerosol physical and chemical properties: An AQMEII-2 perspective, Atmos. Environ., 115, 541-552, 2015.

Diehl, T., Heil, A., Chin, M., Pan, X., Streets, D., Schultz, M., and Kinne, S.: Anthropogenic, biomass burning, and volcanic emissions of black carbon, organic carbon, and $\mathrm{SO}_{2}$ from 1980 to 2010 for hindcast model experiments, Atmos. Chem. Phys. Discuss., 12, 24895-24954, doi:10.5194/acpd-12-24895-2012, 2012.

Favez, O., Alfaro, S. C., Sciare, J., Cachier, H., and Abdelwahab, M. M.: Ambient measurements of light-absorption by agricultural waste burning organic aerosols, J. Aerosol Sci., 40, 613620, 2009

Feng, Y., Ramanathan, V., and Kotamarthi, V. R.: Brown carbon: a significant atmospheric absorber of solar radiation?, Atmos. Chem. Phys., 13, 8607-8621, doi:10.5194/acp-13-8607-2013, 2013.

Fernandes, S. D., Trautmann, N. M., Streets, D. G., Roden, C. A., and Bond, T. C.: Global biofuel use, 1850-2000, Global Biogeochem. Cy., 21, GB2019, 2007.

Flores, J. M., Washenfelder, R., Adler, G., Lee, H., Segev, L., Laskin, J., Laskin, A., Nizkorodov, S., Brown, S., and Rudich, Y.: Complex refractive indices in the near-ultraviolet spectral region of biogenic secondary organic aerosol aged with ammonia, Phys. Chem. Chem. Phys., 16, 10629-10642, 2014.

Forster, P. V., Ramaswamy, P., Artaxo, T., Berntsen, R., Betts, D. W., Fahey, J., Haywood, J., Lean, D. C., Lowe, G., Myhre, J., Nganga, R., Prinn, G., Raga, M. S., and Dorland, R. V.: Changes in Atmospheric Constituents and in Radiative Forcing., Cambridge University Press, United Kingdom and New York, NY, USA, 2007.

Goldstein, A. H. and Galbally, I. E.: Known and unexplored organic constituents in the earth's atmosphere, Environ. Sci. Technol., 41, 1514-1521, 2007.

Graber, E. R. and Rudich, Y.: Atmospheric HULIS: How humic-like are they? A comprehensive and critical review, Atmos. Chem. Phys., 6, 729-753, doi:10.5194/acp-6-729-2006, 2006.

Granier, C., Bessagnet, B., Bond, T., D’Angiola, A., Denier van der Gon, H., Frost, G. J., Heil, A., Kaiser, J. W., Kinne, S., and Klimont, Z.: Evolution of anthropogenic and biomass burning emissions of air pollutants at global and regional scales during the 1980-2010 period, Climatic Change, 109, 163-190, 2011.

Hawkins, L. N., Baril, M. J., Sedehi, N., Galloway, M. M., De Haan, D. O., Schill, G. P., and Tolbert, M. A.: Formation of Semisolid, Oligomerized Aqueous SOA: Lab Simulations of Cloud Processing, Environ. Sci. Technol., 48, 2273-2280, 2014.

Heald, C. L., Ridley, D. A., Kroll, J. H., Barrett, S. R. H., CadyPereira, K. E., Alvarado, M. J., and Holmes, C. D.: Contrasting the direct radiative effect and direct radiative forcing of aerosols, Atmos. Chem. Phys., 14, 5513-5527, doi:10.5194/acp-14-55132014, 2014.

Hecobian, A., Zhang, X., Zheng, M., Frank, N., Edgerton, E. S., and Weber, R. J.: Water-Soluble Organic Aerosol material and the light-absorption characteristics of aqueous extracts measured over the Southeastern United States, Atmos. Chem. Phys., 10, 5965-5977, doi:10.5194/acp-10-5965-2010, 2010.

Henze, D. K. and Seinfeld, J. H.: Global secondary organic aerosol from isoprene oxidation, Geophys. Res. Lett., 33, L09812, doi:10.1029/2006GL025976, 2006.

Henze, D. K., Seinfeld, J. H., Ng, N. L., Kroll, J. H., Fu, T.-M., Jacob, D. J., and Heald, C. L.: Global modeling of secondary organic aerosol formation from aromatic hydrocarbons: highvs. low-yield pathways, Atmos. Chem. Phys., 8, 2405-2420, doi:10.5194/acp-8-2405-2008, 2008.

Hoffer, A., Gelencsér, A., Guyon, P., Kiss, G., Schmid, O., Frank, G. P., Artaxo, P., and Andreae, M. O.: Optical properties of humic-like substances (HULIS) in biomass-burning aerosols, Atmos. Chem. Phys., 6, 3563-3570, doi:10.5194/acp-6-3563-2006, 2006.

Huang, Y., Wu, S., Dubey, M. K., and French, N. H. F.: Impact of aging mechanism on model simulated carbonaceous aerosols, Atmos. Chem. Phys., 13, 6329-6343, doi:10.5194/acp-13-63292013, 2013.

Iacono, M. J., Delamere, J. S., Mlawer, E. J., Shephard, M. W., Clough, S. A., and Collins, W. D.: Radiative forcing by long-lived greenhouse gases: Calculations with the AER radiative transfer models, J. Geophys. Res., 113, D13103, doi:10.1029/2008JD009944, 2008.

Jacobson, M. Z.: Isolating nitrated and aromatic aerosols and nitrated aromatic gases as sources of ultraviolet light absorption, $\mathrm{J}$. Geophys. Res., 104, 3527-3542, 1999.

Jacobson, M. Z.: Global direct radiative forcing due to multicomponent anthropogenic and natural aerosols, J. Geophys. Res., 106, 1551-1568, 2001

Jaoui, M., Edney, E. O., Kleindienst, T. E., Lewandowski, M., Offenberg, J. H., Surratt, J. D., and Seinfeld, J. H.: Formation of secondary organic aerosol from irradiated alpha-pinene/toluene/ $\mathrm{NO}_{x}$ mixtures and the effect of isoprene and sulfur dioxide, J. Geophys. Res., 113, D09303, doi:10.1029/2007JD009426, 2008.

Jiang, X., Wiedinmyer, C., and Carlton, A. G.: Aerosols from fires: An examination of the effects on ozone photochemistry in the Western United States, Environ. Sci. Technol., 46, 11878-11886, 2012.

Jo, D., Park, R., Kim, M., and Spracklen, D.: Effects of chemical aging on global secondary organic aerosol using the volatility basis set approach, Atmos. Environ., 81, 230-244, 2013.

Kaufman, Y. J., Justice, C. O., Flynn, L. P., Kendall, J. D., Prins, E. M., Giglio, L., Ward, D. E., Menzel, W. P., and Setzer, A. W.: Potential global fire monitoring from EOS-MODIS, J. Geophys. Res., 103, 32215-32238, 1998.

Kim, H. and Paulson, S. E.: Real refractive indices and volatility of secondary organic aerosol generated from photooxidation and ozonolysis of limonene, $\alpha$-pinene and toluene, Atmos. Chem. Phys., 13, 7711-7723, doi:10.5194/acp-13-7711-2013, 2013.

Kirchstetter, T. W. and Thatcher, T. L.: Contribution of organic carbon to wood smoke particulate matter absorption of solar radiation, Atmos. Chem. Phys., 12, 6067-6072, doi:10.5194/acp-126067-2012, 2012.

Kirchstetter, T. W., Novakov, T., and Hobbs, P. V.: Evidence that the spectral dependence of light absorption by aerosols is affected by organic carbon, J. Geophys. Res., 109, D21208, doi:10.1029/2004JD004999, 2004. 
Lamarque, J.-F., Bond, T. C., Eyring, V., Granier, C., Heil, A., Klimont, Z., Lee, D., Liousse, C., Mieville, A., Owen, B., Schultz, M. G., Shindell, D., Smith, S. J., Stehfest, E., Van Aardenne, J., Cooper, O. R., Kainuma, M., Mahowald, N., McConnell, J. R., Naik, V., Riahi, K., and van Vuuren, D. P.: Historical (1850-2000) gridded anthropogenic and biomass burning emissions of reactive gases and aerosols: methodology and application, Atmos. Chem. Phys., 10, 7017-7039, doi:10.5194/acp10-7017-2010, 2010.

Lambe, A. T., Cappa, C. D., Massoli, P., Onasch, T., Forestieri, S. D., Martin, A. T., Cummings, M. J., Croasdale, D. R., Brune, B., and Worsnop, D. R.: Relationship between oxidation level and optical properties of secondary organic aerosol, Environ. Sci. Technol., 47, 6349-6357, 2013.

Laskin, A., Laskin, J., and Nizkorodov, S. A.: Chemistry of Atmospheric Brown Carbon, Chem. Rev., 115, 4335-4382, 2015.

Laskin, J., Laskin, A., Roach, P. J., Slysz, G. W., Anderson, G. A., Nizkorodov, S. A., Bones, D. L., and Nguyen, L. Q.: Highresolution desorption electrospray ionization mass spectrometry for chemical characterization of organic aerosols, Anal. Chem., 82, 2048-2058, 2010.

Laskin, J., Laskin, A., Nizkorodov, S. A., Roach, P., Eckert, P., Gilles, M. K., Wang, B., Lee, H. J., and Hu, Q.: Molecular Selectivity of Brown Carbon Chromophores, Environ. Sci. Technol., 48, 12047-12055, 2014

Liao, H., Henze, D., Seinfeld, J., Wu, S., and Mickley, L.: Biogenic secondary organic aerosol over the United States: Comparison of climatological simulations with observations, J. Geophys. Res., 112, D06201, doi:10.1029/2006JD007813, 2007.

Lin, G., Penner, J. E., Flanner, M. G., Sillman, S., Xu, L., and Zhou, C.: Radiative forcing of organic aerosol in the atmosphere and on snow: Effects of SOA and brown carbon, J. Geophys. Res.Atmos., 119, 7453-7476, 2014.

Lin, P., Liu, J., Shilling, J. E., Kathmann, S. M., Laskin, J., and Laskin, A.: Molecular characterization of brown carbon $(\mathrm{BrC})$ chromophores in secondary organic aerosol generated from photo-oxidation of toluene, Phys. Chem. Chem. Phys., 17, 23312-23325, doi:10.1039/c5cp02563j, 2015.

Liu, J., Scheuer, E., Dibb, J., Ziemba, L. D., Thornhill, K., Anderson, B. E., Wisthaler, A., Mikoviny, T., Devi, J. J., and Bergin, M.: Brown carbon in the continental troposphere, Geophys. Res. Lett., 41, 2191-2195, 2014

Liu, S., Shilling, J. E., Song, C., Hiranuma, N., Zaveri, R. A., and Russell, L. M.: Hydrolysis of organonitrate functional groups in aerosol particles, Aerosol Sci. Technol. 46, 1359-1369, 2012.

Lukács, H., Gelencsér, A., Hammer, S., Puxbaum, H., Pio, C., Legrand, M., Kasper-Giebl, A., Handler, M., Limbeck, A., and Simpson, D.: Seasonal trends and possible sources of brown carbon based on 2-year aerosol measurements at six sites in Europe, J. Geophys. Res., 112, D23S18, doi:10.1029/2006JD008151, 2007.

Malm, W. C., Sisler, J. F., Huffman, D., Eldred, R. A., and Cahill, T. A.: Spatial and seasonal trends in particle concentration and optical extinction in the United States, J. Geophys. Res., 99, 13471370, 1994.

Martin, R. V., Jacob, D. J., Yantosca, R. M., Chin, M., and Ginoux, P.: Global and regional decreases in tropospheric oxidants from photochemical effects of aerosols, J. Geophys. Res., 108, 4097, doi:10.1029/2002JD002622, 2003.
McMeeking, G. R.: The Optical, Chemical, And Physical Properties Of Aerosols And Gases Emitted By The Laboratory Combustion Of Wildland Fuels, Dissertation, Department of Atmospheric Science, Colorado State University, Fort Collins, Colorado Fall 2008, available at: http://chem.atmos.colostate.edu/ Thesis/McMeeking\%20dissertation.pdf (last access: 14 March 2016), 2008

Mischenko, M. I., Travis, L. D., and Lacis, A. A.: Scattering, Absorption, and Emission of Light by Small Particles, Cambridge University Press, UK, 2002.

Moise, T., Flores, J. M., and Rudich, Y.: Optical Properties of Secondary Organic Aerosols and Their Changes by Chemical Processes, Chem. Rev., 115, 4400-4439, 2015.

Murphy, B. N. and Pandis, S. N.: Exploring summertime organic aerosol formation in the eastern United States using a regionalscale budget approach and ambient measurements, J. Geophys Res., 115, D24216, doi:10.1029/2010JD014418, 2010.

Myhre, G., Samset, B. H., Schulz, M., Balkanski, Y., Bauer, S., Berntsen, T. K., Bian, H., Bellouin, N., Chin, M., Diehl, T., Easter, R. C., Feichter, J., Ghan, S. J., Hauglustaine, D., Iversen, T., Kinne, S., Kirkevåg, A., Lamarque, J.-F., Lin, G., Liu, X., Lund, M. T., Luo, G., Ma, X., van Noije, T., Penner, J. E., Rasch, P. J., Ruiz, A., Seland, Ø., Skeie, R. B., Stier, P., Takemura, T., Tsigaridis, K., Wang, P., Wang, Z., Xu, L., Yu, H., Yu, F., Yoon, J.-H., Zhang, K., Zhang, H., and Zhou, C.: Radiative forcing of the direct aerosol effect from AeroCom Phase II simulations, Atmos. Chem. Phys., 13, 1853-1877, doi:10.5194/acp-13-18532013, 2013.

Nakayama, T., Matsumi, Y., Sato, K., Imamura, T., Yamazaki, A., and Uchiyama, A.: Laboratory studies on optical properties of secondary organic aerosols generated during the photooxidation of toluene and the ozonolysis of $\alpha$-pinene, J. Geophys. Res., 115, D24204, doi:10.1029/2010JD014387, 2010.

Nakayama, T., Sato, K., Matsumi, Y., Imamura, T., Yamazaki, A., and Uchiyama, A.: Wavelength and $\mathrm{NO}_{x}$ dependent complex refractive index of SOAs generated from the photooxidation of toluene, Atmos. Chem. Phys., 13, 531-545, doi:10.5194/acp-13531-2013, 2013.

Nguyen, T. B., Lee, P. B., Updyke, K. M., Bones, D. L., Laskin, J., Laskin, A., and Nizkorodov, S. A.: Formation of nitrogenand sulfur-containing light-absorbing compounds accelerated by evaporation of water from secondary organic aerosols, J. Geophys. Res., 117, D01207, doi:10.1029/2011JD016944, 2012.

Park, R. J., Jacob, D. J., Chin, M., and Martin, R. V.: Sources of carbonaceous aerosols over the United States and implications for natural visibility, J. Geophys. Res., 108, 4355, doi:10.1029/2002JD003190, 2003.

Park, R. J., Jacob, D. J., Kumar, N., and Yantosca, R. M.: Regional visibility statistics in the United States: Natural and transboundary pollution influences, and implications for the Regional Haze Rule, Atmos. Environ., 40, 5405-5423, 2006.

Park, R. J., Kim, M. J., Jeong, J. I., Youn, D., and Kim, S.: A contribution of brown carbon aerosol to the aerosol light absorption and its radiative forcing in East Asia, Atmos. Environ., 44, 1414 1421, 2010.

Reid, J. S., Koppmann, R., Eck, T. F., and Eleuterio, D. P.: A review of biomass burning emissions part II: intensive physical properties of biomass burning particles, Atmos. Chem. Phys., 5, 799825, doi:10.5194/acp-5-799-2005, 2005. 
Rienecker, M. M., Suarez, M. J., Gelaro, R., Todling, R., Bacmeister, J., Liu, E., Bosilovich, M. G., Schubert, S. D., Takacs, L., and Kim, G.-K.: MERRA: NASA's modern-era retrospective analysis for research and applications, J. Climate, 24, 3624-3648, 2011.

Saleh, R., Robinson, E. S., Tkacik, D. S., Ahern, A. T., Liu, S., Aiken, A. C., Sullivan, R. C., Presto, A. A., Dubey, M. K., and Yokelson, R. J.: Brownness of organics in aerosols from biomass burning linked to their black carbon content, Nat. Geosci., 7, 647-650, 2014.

Sareen, N., Moussa, S. G., and McNeill, V. F.: Photochemical Aging of Light-Absorbing Secondary Organic Aerosol Material, J. Phys. Chem. A, 117, 2987-2996, 2013.

Schnaiter, M., Gimmler, M., Llamas, I., Linke, C., Jäger, C., and Mutschke, H.: Strong spectral dependence of light absorption by organic carbon particles formed by propane combustion, Atmos. Chem. Phys., 6, 2981-2990, doi:10.5194/acp-6-2981-2006, 2006.

Srinivas, B. and Sarin, M.: Brown carbon in atmospheric outflow from the Indo-Gangetic Plain: Mass absorption efficiency and temporal variability, Atmos. Environ., 89, 835-843, 2014.

Turpin, B. J. and Lim, H. J.: Species contributions to $\mathrm{PM}_{2.5}$ mass concentrations: Revisiting common assumptions for estimating organic mass, Aerosol Sci. Tech., 35, 602-610, 2001.

Updyke, K. M., Nguyen, T. B., and Nizkorodov, S. A.: Formation of Brown Carbon via Reactions of Ammonia with Secondary Organic Aerosols from Biogenic and Anthropogenic Precursors, Atmos. Environ., 63, 22-31, 2012.

Wang, X., Heald, C. L., Ridley, D. A., Schwarz, J. P., Spackman, J. R., Perring, A. E., Coe, H., Liu, D., and Clarke, A. D.: Exploiting simultaneous observational constraints on mass and absorption to estimate the global direct radiative forcing of black carbon and brown carbon, Atmos. Chem. Phys., 14, 10989-11010, doi:10.5194/acp-14-10989-2014, 2014.

Ward, D., Susott, R., Kauffman, J., Babbitt, R., Cummings, D., Dias, B., Holben, B., Kaufman, Y., Rasmussen, R., and Setzer, A.: Smoke and Fire Characteristics for Cerrado and Deforestation Burns in Brazil: BASE-B Experiment, Journal of Geophysical Research, 97, 14601-14619, 1992.

Ward, D. E. and Hao, W.: Projections of Emissions from Burning of Biomass Foruse in Studies of Global Climate and Atmospheric Chemistry, Air and Waste Management Association, Vancouver, British Colombia, Canada, 1991.
Weber, R. J., Sullivan, A. P., Peltier, R. E., Russell, A., Yan, B., Zheng, M., de Gouw, J., Warneke, C., Brock, C., and Holloway, J. S.: A study of secondary organic aerosol formation in the anthropogenic-influenced southeastern United States, J. Geophys. Res., 112, D13302, doi:10.1029/2007JD008408, 2007.

Wiedinmyer, C., Akagi, S. K., Yokelson, R. J., Emmons, L. K., AlSaadi, J. A., Orlando, J. J., and Soja, A. J.: The Fire INventory from NCAR (FINN): a high resolution global model to estimate the emissions from open burning, Geosci. Model Dev., 4, 625641, doi:10.5194/gmd-4-625-2011, 2011.

Yang, M., Howell, S. G., Zhuang, J., and Huebert, B. J.: Attribution of aerosol light absorption to black carbon, brown carbon, and dust in China - interpretations of atmospheric measurements during EAST-AIRE, Atmos. Chem. Phys., 9, 2035-2050, doi:10.5194/acp-9-2035-2009, 2009.

Yu, L., Smith, J., Laskin, A., Anastasio, C., Laskin, J., and Zhang, Q.: Chemical characterization of SOA formed from aqueousphase reactions of phenols with the triplet excited state of carbonyl and hydroxyl radical, Atmos. Chem. Phys., 14, 1380113816, doi:10.5194/acp-14-13801-2014, 2014.

Zhang, X., Lin, Y. H., Surratt, J. D., Zotter, P., Prévôt, A. S. H., and Weber, R. J.: Light-absorbing soluble organic aerosol in Los Angeles and Atlanta: A contrast in secondary organic aerosol, Geophys. Res. Lett., 38, L21810, doi:10.1029/2011GL049385, 2011.

Zhang, X., Lin, Y.-H., Surratt, J. D., and Weber, R. J.: Sources, Composition and Absorption Ångström Exponent of Lightabsorbing Organic Components in Aerosol Extracts from the Los Angeles Basin, Environ. Sci. Technol., 47, 3685-3693, doi:10.1021/es305047b, 2013.

Zhong, M. and Jang, M.: Light absorption coefficient measurement of SOA using a UV-Visible spectrometer connected with an integrating sphere, Atmos. Environ., 45, 4263-4271, 2011.

Zhong, M., Jang, M., Oliferenko, A., Pillai, G. G., and Katritzky, A. R.: The SOA Formation Model Combined with Semiempirical Quantum Chemistry to Predict UV-Vis Absorption of Secondary Organic Aerosols, Phys. Chem. Chem. Phys., 14, 90589066, 2012. 